\title{
A Meta-Analysis of Prosocial Media on Prosocial Behavior, Aggression, and Empathic Concern: A Multidimensional Approach
}

\author{
Sarah M. Coyne \\ Brigham Young University - Provo \\ Laura M. Padilla-Walker \\ Brigham Young University - Provo \\ Hailey G. Holmgren \\ Brigham Young University - Provo \\ Emilie J. Davis \\ Brigham Young University - Provo \\ Relvirwithi@arllileadditional works at: https://scholarsarchive.byu.edu/facpub \\ Be Ohio State University \\ Part of the Other Social and Behavioral Sciences Commons
}

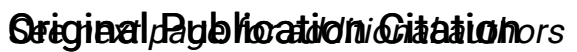

Coyne, S. M., Walker, L. P., Holmgren, H., Davis, E., Collier, K., Memmott-Elison, M., \& Hawkins, A. J. (2017). A meta-analysis of prosocial media on prosocial behavior, aggression, and empathic concern: A multidimensional approach. Developmental Psychology.

\section{BYU ScholarsArchive Citation}

Coyne, Sarah M.; Padilla-Walker, Laura M.; Holmgren, Hailey G.; Davis, Emilie J.; Collier, Kevin M.; Memmott-Elison, Madison K.; and Hawkins, Alan J., "A Meta-Analysis of Prosocial Media on Prosocial Behavior, Aggression, and Empathic Concern: A Multidimensional Approach" (2017). Faculty Publications. 4253.

https://scholarsarchive.byu.edu/facpub/4253

This Peer-Reviewed Article is brought to you for free and open access by BYU ScholarsArchive. It has been accepted for inclusion in Faculty Publications by an authorized administrator of BYU ScholarsArchive. For more information, please contact ellen_amatangelo@byu.edu. 


\section{Authors}

Sarah M. Coyne, Laura M. Padilla-Walker, Hailey G. Holmgren, Emilie J. Davis, Kevin M. Collier, Madison K. Memmott-Elison, and Alan J. Hawkins 


\title{
A Meta-Analysis of Prosocial Media on Prosocial Behavior, Aggression, and Empathic Concern: A Multidimensional Approach
}

\author{
Sarah M. Coyne, Laura M. Padilla-Walker, \\ Hailey G. Holmgren, and Emilie J. Davis \\ Brigham Young University
}

\author{
Kevin M. Collier \\ The Ohio State University
}

\author{
Madison K. Memmott-Elison and Alan J. Hawkins \\ Brigham Young University
}

\begin{abstract}
Studies examining the effects of exposure to prosocial media on positive outcomes are increasing in number and strength. However, existing meta-analyses use a broad definition of prosocial media that does not recognize the multidimensionality of prosocial behavior. The aim of the current study is to conduct a meta-analysis on the effects of exposure to prosocial media on prosocial behavior, aggression, and empathic concern while examining multiple moderators that the prosocial behavior literature suggests are important to our understanding of why individuals voluntarily help others (e.g., target, type, cost). Results from 72 studies involving 243 effect sizes revealed that exposure to prosocial media was related to higher levels of prosocial behavior and empathic concern and lower levels of aggressive behavior. Moderation analyses suggest that several moderators accounted for heterogeneity in the model, including age of participant, region, media type (active vs. passive), and study design. In terms of multidimensional moderators, prosocial media had stronger effects on prosocial behavior toward strangers than did any other target and on helping and prosocial thinking but not donating or volunteering. Comparisons with other meta-analyses on media effects are made and implications for parents, media producers, and researchers are discussed.
\end{abstract}

Keywords: prosocial behavior, media, aggression, empathy, meta-analysis

General media exposure has drastically increased in the last 2 decades, with children and adolescents ages 8 to 18 being exposed to between 6 and $9 \mathrm{hrs}$ of media content per day (Rideout, 2015). As such, there is a great deal of research that examines various effects of media use, including both time spent with media and specific media content. Research has found negative effects of excessive time spent engaged in media use (Gentile, 2009), and research on media content has identified both positive and negative content that has varying effects (Greitemeyer \& Mügge, 2014). The majority of research examining media content has explored the effects of aggressive or violent media, finding that it is linked to a host of negative outcomes (e.g., Anderson et al., 2010; Bushman \& Huesmann, 2006; Gentile, 2014; Greitemeyer \& Mugge, 2014). However, there is less research examining the impact of prosocial media content (e.g., content depicting helpful-

This article was published Online First October 30, 2017.

Sarah M. Coyne, Laura M. Padilla-Walker, Hailey G. Holmgren, and Emilie J. Davis, School of Family Life, Brigham Young University; Kevin M. Collier, Department of Communications, The Ohio State University; Madison K. Memmott-Elison and Alan J. Hawkins, School of Family Life, Brigham Young University.

Portions of this article were presented at the International Society for Research Aggression conference in July 19-23, 2016, Sydney, Australia.

Correspondence concerning this article should be addressed to Sarah M. Coyne, School of Family Life, Brigham Young University, JFSB 2087, Provo, UT 84602. E-mail: smcoyne@byu.edu ness, kindness, sharing) on children and adolescents, despite a growing body of research suggesting the positive and even protective role of prosocial behavior (e.g., Padilla-Walker, Carlo, \& Nielson, 2015) and exposure to prosocial content in the media (Coyne \& Smith, 2014; Prot et al., 2014). Thus, the current study seeks to use a meta-analytic approach to examine how prosocial media content relates to prosocial behavior, empathic concern, and aggressive behavior across the life span.

\section{Prosocial Media Content}

Prosocial media content entails media depictions of prosocial behavior (Smith et al., 2006), which is defined as voluntary behavior with the intention of benefiting others (Eisenberg, Fabes, \& Spinrad, 2006). Prosocial behavior occurs regularly in the media (Coyne \& Smith, 2014), including in TV (Smith et al., 2006), video games (Dill, Gentile, Richter, \& Dill, 2005), music, (Greitemeyer, 2011), books (Trepanier, \& Romatowski, 1982), social media, and the Internet (Coyne, Padilla-Walker, \& Howard, 2013). Prosocial content is particularly common in children's programming compared with adult programming (Smith et al., 2006). For example, research has found high rates of prosocial behavior in Disney movies, which display approximately one act of prosocial behavior per minute (Padilla-Walker, Coyne, Fraser, \& Stockdale, 2013). Exposure to prosocial media content tends to have a somewhat consistent effect on users (Mares \& Woodard, 2005), being linked to higher levels of empathic concern (Prot et al., 2014) and prosocial behavior (Gentile et al., 2009; Mano, 2014; Prot et al., 
2014), and lower levels of aggression (Eisenberg \& Mussen, 1989; Padilla-Walker, Coyne, Collier, \& Nielson, 2015), aggressive cognition, and aggressive affect (Greitemeyer, 2011). Therefore, prosocial media content is related to not only increased positive behaviors, but also decreased negative behaviors.

\section{Multidimensionality of Prosocial Behavior}

One of the limitations of existing research on prosocial media content is the narrow way in which prosocial media and prosocial behavior have been defined. Some studies have looked broadly at positive interactions (e.g., Mares \& Woodard, 2005), whereas others have focused only on altruistic prosocial behavior (Smith et al., 2006). We argue that the way we measure prosocial media should more closely mirror the way that developmental scholars measure prosocial behavior, which is with an ever-increasing eye toward the multidimensional nature of prosocial behavior (PadillaWalker \& Carlo, 2014). For example, research suggests that there are different targets or recipients of prosocial behavior and that helping one target may be differentially motivated (Padilla-Walker \& Christensen, 2011) and may protect against negative outcomes (Padilla-Walker, Carlo, et al., 2015) more directly than does helping other targets. There are also distinct types of prosocial behavior that differ in their antecedents and consequences (e.g., sharing, caring, helping, donating; see Laible \& Karahuta, 2014; PadillaWalker \& Carlo, 2014). Other distinctions have been made between prosocial behavior that is high cost (e.g., extensive volunteering, helping in dangerous or emergency situations) and behavior that is relatively low cost (e.g., helping to pick up a dropped item, sending an uplifting text message; Eisenberg \& Spinrad, 2014). These are but a few examples of the ways in which the prosocial literature is beginning to examine prosocial behavior in a more nuanced way. Although no single media-content study has captured all of the nuances of prosocial behavior, studies that have considered multidimensional prosocial media content (e.g., Padilla-Walker et al., 2013) suggest that there is substantially more prosocial content in children's media than has been suggested by studies that have considered more limited or general definitions of prosocial behavior (e.g., Smith et al., 2006). In addition, research has found that prosocial media content may be associated with prosocial behavior toward some prosocial targets, but not toward others (Padilla-Walker et al., 2015). Taken together, these studies suggest that current research may underestimate the prevalence and the strength of prosocial content, so in the current study we sought to include studies with a broad definition of prosocial (but not just positive) behavior so that we could examine potential moderation effects as a function of multidimensional aspects of prosocial content.

\section{Theoretical Basis}

The general learning model (GLM) explains how viewing any type of behavior (such as prosocial behavior) in the media might influence behaviors (Buckley \& Anderson, 2006). This theory examines both short- and long-term effects of viewing media and is a generalization of the general aggression model to apply the same basic psychological concepts and processes to nonaggressive outcomes (Anderson \& Bushman, 2002). In the short-term, exposure to prosocial media may influence a person's internal state in three different ways. More specifically, viewing such material might influence one's affect, by putting them in a good mood; their arousal, by lowering blood pressure and decreasing cortisol; and their cognition, by activating prosocial related scripts in memory. Activation of these scripts may be strengthened if the behavior being modeled in the media is congruent with a real-life situation. For example, the individual might be asked to volunteer with their local youth group or may have a friend ask for help moving to a new apartment the following weekend. According to the GLM, the individual's present internal state will influence their decisionmaking process on whether or not to help, and this may be moderated by the situation (e.g., target, cost). Hypothetically, after viewing prosocial media, this individual would be more likely to be prosocial in this example and may be more likely to help a friend than a stranger. We include measures of behavior, affect, arousal, and cognition relating to our outcome variables, given that all should hypothetically be influenced by prosocial media according to GLM.

In the long-term, prosocial media may influence the creation and strength of cognitive scripts, normative beliefs or values, prosocial goals, and perceptual schema related to prosocial behavior. This could shape the way in which an individual might think about the acceptability of certain types of behavior and their own abilities and intentions to act (based on prosocial identity developed over time). Again, these links could be hypothesized to vary as a function of the situation (e.g., because of experience one might develop clear values and goals around helping in high-cost emergency situations but might not have developed values around helping in more low-cost situations). The long-term impact of socialization influences (i.e., media, in this case) would be that these established scripts, values, goals and schemas would result in a prosocial identity that may influence behavior over a lifetime.

\section{Existing Meta-Analyses}

To our knowledge, there are four meta-analyses on the effects of exposure to prosocial behavior in the media, each occurring approximately 10 years apart. Early meta-analyses suggested that prosocial media has a positive influence on positive behaviors, though many studies included did not specifically measure prosocial behavior in the media or as an outcome (Hearold, 1986; Mares, 1996). For example, many studies included such positive behaviors as reducing negative stereotypes or buying books.

Mares and Woodard (2005) conducted the most complete metaanalysis on prosocial media content, including 34 studies, and found the overall effect size of prosocial content to be $r=.23$, which is comparable to the overall effect size of violent content on aggressive behavior found in other studies. It is also of note that prosocial content had the strongest impact on what we would consider to be the only prosocial outcome assessed, altruism ( $r=$ .37). Mares and Woodard also assessed several moderators in their analyses to help account for the relationship between media viewing and prosocial outcomes, including age, gender, and ethnicity. Though gender and ethnicity did not act as moderators, age yielded significant moderating effects, with the strongest effects of prosocial behavior peaking around age 7 and declining steeply afterward.

Greitemeyer and Mügge (2014) also conducted a recent metaanalysis, where the effects of violent video games on users were 
examined, with effects of prosocial video games as a comparison. Meta-analytic analyses of 25 independent studies revealed prosocial video game play was linked to decreased aggressive behavior $(r=-.16)$, cognition $(r=-.30)$, and affect $(r=-.35)$ and increased prosocial behavior $(r=.20)$, cognition $(r=.42)$, and affect $(r=.25)$. The effect sizes of violent and prosocial video games were not statistically different, and few moderators were investigated. Although this meta-analysis is the most recent, it notably only examined the effects of video games, and prosocial video games are quite rare and not representative of prosocial media overall (Coyne \& Smith, 2014).

Taken together, though much is to be gained from these studies, an update is warranted because only 34 studies were included in Mares and Woodard's (2005) study, the majority of which were published prior to 1990 . Also, the media climate and devices have changed a great deal in the last 10 years, and there is a need to examine the effects of media overall (not just video games: Greitemeyer \& Mügge, 2014) on behavior. Further, Mares and Woodard's definition of prosocial behavior was rather limited, including altruism, but then focusing on positive (but not prosocial) behaviors including positive interaction, decreased aggression, and stereotype reduction. Moreover, there is a need to examine the effects of prosocial media from a multidimensional perspective.

\section{Potential Moderators of Prosocial Media Content}

In the current study, we explored a number of potential moderators. First, research has found that media effects may be different depending on the age of the individual (Coyne \& Smith, 2014). Several previous meta-analyses have done this and have suggested that the effects of prosocial media peak at age 7 and decline thereafter, but these analyses included only children and adolescents (e.g., Mares \& Woodard, 2005) or did not assess age as a moderator (e.g., Greitemeyer \& Mügge, 2014). Given the stability of prosocial behavior and the smaller effect of socialization influences, including media, on behavior as children age (Padilla-Walker, Coyne, et al., 2015), it is possible that prosocial content will have a smaller effect on emerging adults and adults. It is also possible that, similar to the effect of violent content, prosocial content may have a longer term effect in the formative years but more of a short-term effect in adulthood (Bushman \& Huesmann, 2006). Thus, the current study will assess these possibilities by examining prosocial media effects on children, adolescents, emerging adults, and adults. Consistent with past meta-analyses, we will also consider sex of the child, geographical region, media type (active vs. passive), and study design as potential moderators. In regard to media type, we made a distinction between different mediums in the current study, examining passive media (such as TV, movies, and music) and active media (such as video games and virtual reality) to determine whether there are differential effects of one type compared to others. Research has found consistent effects of active media (e.g., Greitemeyer \& Mügge, 2014), but the results of passive media have been less consistent, at least longitudinally (Padilla-Walker et al., 2015). We thought it was possible that active media may have a stronger effect on behavior given that active media tends to be a more immersive experience overall (Persky \& Blascovich, 2007; Lull \& Bushman, 2016). Indeed, research on aggressive media content suggests that active participation is more strongly associated with behavior than passive participation, though this type of research is less common when assessing prosocial content.

To fully capture the effects of prosocial content on viewers, we also chose to consider multidimensional aspects of prosocial behavior as potential moderators of the effects of media content on child outcomes including target or recipient, type, and cost of prosocial behavior. More specifically, developmental literature has identified at least three targets toward whom individuals regularly are prosocial, including strangers, friends, and family members. The clearest theoretical distinction is made between prosocial behavior toward those with whom the child is in a relationship (e.g., friends and family) as compared with those who are relative strangers. These approaches and existing empirical work suggest differences in (a) frequency of prosocial behavior as a function of target (Padilla-Walker \& Christensen, 2011), (b) motivation for prosocial behavior toward family members compared with other targets (Lewis, 2014), and (c) outcomes of helping one target compared with another (Padilla-Walker, Carlo, et al., 2015). Because other socialization influences have been found to differentially impact different targets of prosocial behavior, there also is likely utility in distinguishing between how media effects might vary as a function of prosocial target. Given the one study of which we are aware that considered prosocial target found aggressive media content was negatively associated only with prosocial behavior toward strangers, it is possible that this will also be the case for prosocial media content. However, we were reluctant to make specific hypotheses in this regard and considered these analyses exploratory.

Developmental research also distinguishes between different types of prosocial behavior, and does this in a variety of ways. Some research has looked at different prosocial tendencies to help in different contexts (e.g., dire, emotional, altruistic; Carlo \& Randall, 2002), while other research considers different types of prosocial behavior (e.g., emotional support or caring, helping, sharing, donating, volunteering, prosocial cognition). Though research has examined different types of prosocial behaviors, few studies compare one type to another in a way that allows us to make generalizations across age groups, but existing research does suggest that frequency, socialization, and motivation of different types of prosocial behaviors are different during the formative years (Eisenberg \& Spinrad, 2014; Laible \& Karahuta, 2014) and researchers have also extended this work to adolescence and young adulthood (e.g., Nielson, Padilla-Walker, \& Holmes, 2017). Given the relative paucity of relevant research, especially in regard to media content, we did not have specific hypotheses in this regard, but considered a number of different types of prosocial behavior that we thought were widely studied and applicable. We also examined prosocial cost as a moderator, as this is a meaningful distinction made in the prosocial literature. More specifically, research has distinguished between prosocial behavior that is of relatively high cost (i.e., requires a significant amount of time or resources from the helper) compared to behavior that is low cost (Eisenberg \& Spinrad, 2014) with the assumption that high-cost prosocial behavior may contribute more importantly to the development of one's moral identity (Padilla-Walker \& Fraser, 
2014). Again, we did not have specific hypotheses in this regard.

\section{Aims of the Current Study}

The purpose of the current study was to conduct a meta-analysis on the effects of prosocial media on various outcomes. This meta-analysis builds on previous studies in a number of key ways. First, this study examined both passive and active media, as other meta-analyses have considered only video games or have not distinguished between mediums. Second, we examined the effect of prosocial media on prosocial behavior, aggression, and empathic concern. Most meta-analyses do not distinguish between prosocial behavior and empathic concern, and though related, they are unique outcomes. Empathic concern (called sympathy in the developmental literature; Eisenberg et al., 2006) is defined as feelings of concern or caring for another individual in need, and though empathic concern often leads to prosocial behavior, it is considered a moral emotion and not a prosocial behavior. Third, we examined prosocial media content and prosocial behavior in a multidimensional fashion, consistent with the literature on prosocial behavior and considered a number of moderators of the effects of prosocial media content, both typical moderators (such as age and sex) and moderators that consider different targets, types, and cost of prosocial behavior.

\section{Method}

\section{Literature Search Procedures}

A four-step process was used to obtain relevant articles. First, from September 2014-April 2015, we conducted a thorough literature search using PsycINFO, MEDLINE, and Communications and Mass Media. There were no restrictions on the time period, geography, or culture in which studies were conducted. On the basis of the prosocial and media literatures, the following terms were searched for throughout the title, abstract, keywords, and entire text of each article: "helping behaviors," "altruism," "kindness," "compassion," "empathy," "sympathy," "prosocial," "volunteering," "donating," and "media," "television," "music," and "video games." Second, the references cited in the Mares and Woodard (2005) and Greitemeyer and Mugge (2014) metaanalyses were examined for appropriateness in the current study. Next, we contacted all authors publishing a minimum of two studies on prosocial media to request any unpublished studies or data.

Our initial search resulted in 2,849 articles, where 120 were deemed by coders as possibly relevant to the study. After screening, 62 articles were omitted as they did not meet the inclusion or exclusion criteria, leaving 58 potential articles. It should be noted that 17 relevant articles could not be coded due to missing relevant statistics. In these cases, we contacted the study authors multiple times for the needed statistics, of which one responded with relevant information. Additionally, in February 2016, we updated our search in PsycINFO, MEDLINE, and Communications and Mass media and found three additional relevant studies, and received three unpublished manuscripts by contacting authors again. Finally, in early 2017, we updated our search in PsychINFO, MEDLINE, and Communications and Mass media added "moral reasoning," "prosocial reasoning," "prosocial cognition," and "prosocial thinking" as search terms and found seven possible relevant articles. We also searched ProQuest Dissertations and Theses, and our original search terms and found 26 additional unpublished studies that were deemed by coders as possibly relevant to the meta-analysis. After further analysis, only seven had appropriate outcomes and statistics for inclusion. In total, the meta-analysis included 72 studies (reported in 54 aricles), using 17,134 participants overall, producing 243 unique effect sizes for the analyses.

\section{Inclusion and Exclusion Criteria}

Articles were determined to be fit for use on the basis of several inclusionary criteria. First, the studies had to contain a measure of prosocial media, defined as voluntary behavior intended to benefit another individual as portrayed in the media. Studies that overtly defined prosocial media as including violence (i.e., killing others to "save" humanity, such as in Halo or Call of Duty) were excluded. Second, studies were included if they measured one of three outcomes, including prosocial behavior (voluntary behavior intended to benefit another individual, also includes prosocial cognition and affect), aggression (behavior intended to hurt another individual, also includes aggressive cognition and affect), or empathic concern (i.e., empathy, sympathy). Third, only studies that measured prosocial behavior in TV, movies, video games, music, or music videos were included. Studies measuring prosocial behavior in other types of media (e.g., books, social media) were excluded from the analysis. Fourth, studies were included if they provided enough statistical information to be used in a metaanalysis. Finally, only studies that were written in English (or could be translated into English) were included (see Figure 1).

\section{Reliability}

Two coders who were trained in media psychology and the inclusionary and exclusionary criteria examined abstracts and text to determine relevance of each article. These coders identified relevant articles and an additional primary author rechecked each article for relevancy. Two trained coders individually coded each relevant article for both moderators and outcomes. Disagreements were rare and coders were required to reach $100 \%$ consensus before the study was entered into the dataset. Cohen's kappa was conducted on all study variables. Acceptable reliability was achieved for each variable, namely, type of publication $(\kappa=1.00)$; sex $(\kappa=1.00)$; age $(\kappa=.75)$; region $(\kappa=1.00)$; media type $(\kappa=1.00)$; study design $(\kappa=1.00)$; target of prosocial behavior $(\kappa=1.00)$; type of prosocial behavior $(\kappa=1.00)$; and cost of prosocial behavior $(\kappa=1.00)$.

As an added precaution, we had an additional two coders recode and recheck all effect size information to ensure accurate coding. Reliability was also at acceptable levels for these additional coders.

\section{Moderators}

A number of potential moderators were coded for each study.

Sex of participant. Sex of participant was noted only when a study provided separate statistics for males and for females. If not, the study was coded as both. 


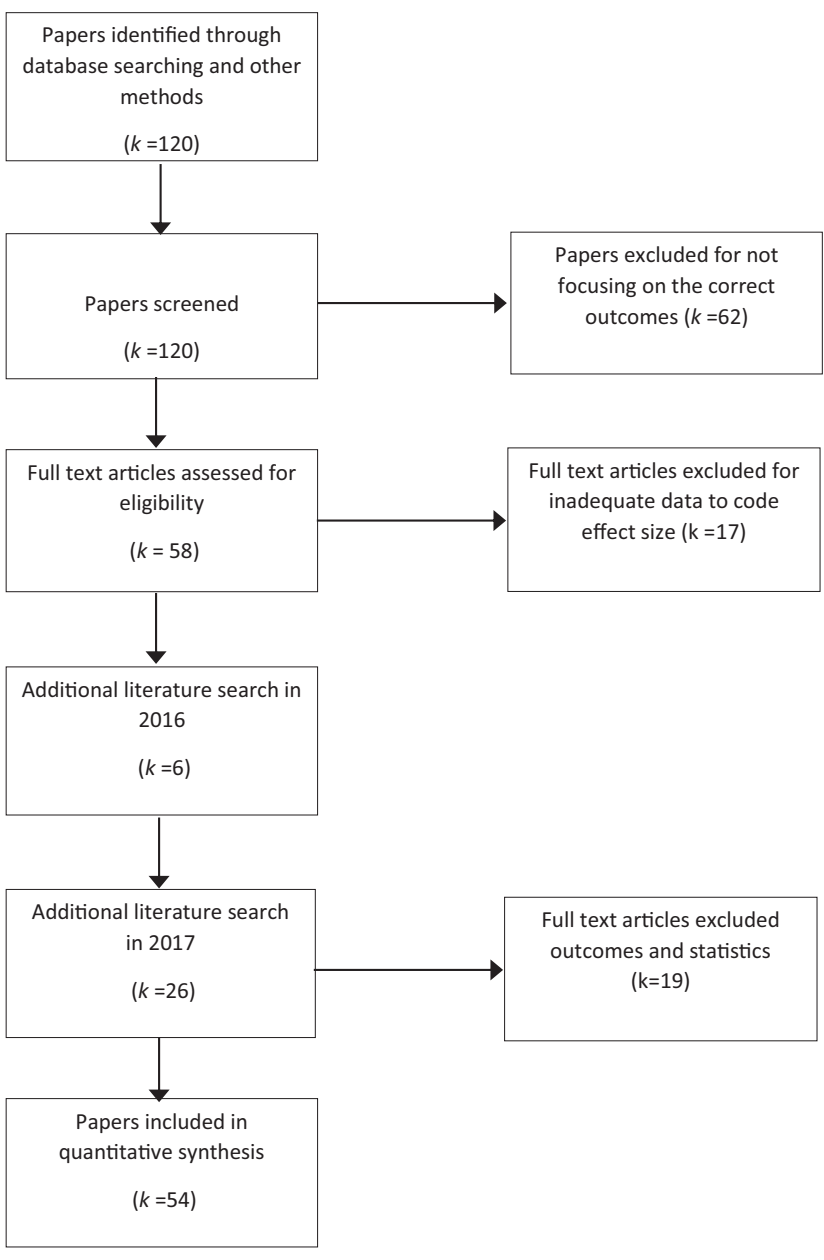

Figure 1. Flowchart for search procedures.

Age of participant. Average age of participant was determined from each relevant article and was coded in one of four categories: childhood ( 0 to 10 years old), adolescence (11 to 17 years old), emerging adult (18 to 25 years old), or adult (25+ years old). In many cases, grade level was included instead of average age level. When this occurred, the average age was computed using the typical age of that reported grade in the United States. For instance, 9th grade was given the value of 15 years old. If a study did not include an average age, but instead reported an age range, the middle of the range was computed. For instance, if the study reported participants spanning from 10 to 13 years old, this study would have an imputed score of 11.5 and would be coded in the adolescence category.

Region. The region in which each of the studies took place was recorded and was placed in one of eight categories: North America, Europe, Asia, Africa, South America, Australia, other, and not specified.

Media type. Media type was coded as one of two categories: active or passive. Active media was defined as media in which the viewer was required to participate in some way (such as in video games or virtual reality). Passive media was defined as media in which the viewer was not required to participate (e.g., watching TV or movie or listening to music).
Study design. Study design was coded as experimental, crosssectional, or longitudinal design. A study was considered an experimental design if participants were assigned to different conditions (experimental or control) where the outcomes for the conditions were compared against each other. A study was considered a cross-sectional design when it determined whether or not two variables were associated with one another. The longitudinal design variable was used for studies which included data from multiple time points, at least one month apart. To code longitudinal studies, we obtained the bivariate correlation between Time 1 prosocial media and Time 2 outcome.

Target of prosocial behavior. Additionally, for the prosocial behavior outcome only, the target of prosocial behavior was coded, including family, friends, or strangers. Family members included parents, siblings, and extended family members; friends included friends, peers, and classmates; and strangers were those with whom the participant did not have a close relationship. If the article was unclear as to who was the target of prosocial behavior, the option for unknown target was used.

Type of prosocial behavior. The prosocial behavior outcome was coded for a variety of behaviors that were trimmed because of low frequency in articles included in our sample. For example, we originally coded for prosocial tendencies (e.g., dire, emotional, etc.), defending behavior, and emotional support, but these types were ultimately dropped. Final types included were helping (e.g., picking up pencils), sharing (e.g., sharing toys), donating (e.g., money), volunteering, prosocial cognitions (e.g., accessibility of prosocial words based on word completion tasks), and unspecified prosocial behavior (e.g., general measures). If articles included more than one subtype of prosocial behavior and did not include separate statistics for each subtype, we coded these as unspecified prosocial behaviors.

Cost of prosocial behavior. The prosocial behavior outcome was coded as either being high cost or low cost. High-cost prosocial behaviors required personal sacrifice from the individual (in terms of time or money) and included behaviors such as donating money (usually used with small children) or volunteering. Lowcost behaviors did not require much personal sacrifice and included behavior such as picking up a dropped pencil or holding the door open for someone. It is important to note that we did not have full manuscripts for all unpublished studies. When coding for these, we e-mailed authors with our definition of high and low cost prosocial behavior. The authors then determined whether their study included low or high cost prosocial behavior.

Greitemeyer. Additionally, $42 \%$ of all studies in the analysis came from the lab of Dr. Tobias Greitemeyer and colleagues. Given the high proportion of studies coming from Dr. Greitemeyer's lab, and the high impact of his research on the analyses in this study, we felt it important to examine whether his studies were different from those of the rest of the field.

\section{Computation of Effect Sizes}

Comprehensive Meta-Analysis III (CMA) software was utilized to analyze the results. Each correlation coefficient underwent a Fisher $z$ transformation to normalize its distribution (Silver \& Dunlap, 1987). Additionally, all $d$ metric effect sizes were converted to the $r$ metric. The average effect size for each outcome was obtained and transformed back into Pearson's $r$ for interpre- 
tation. The pooled estimate of $r$ is denoted as $r_{+}$. Several studies in our analysis reported beta coefficients. The use of beta coefficients in meta-analysis is highly controversial (see Boxer Groves, \& Docherty, 2015; Ferguson, 2015; Rothstein \& Bushman, 2015; Valkenburg, 2015); accordingly, we contacted three authors who reported beta coefficients and obtained the zero order correlations for use in our analysis. CMA was used to examine the overall effect size when each study effect was removed one at a time. There were no substantial changes in the overall effect size.

Many of our studies reported multiple effect sizes of interest (e.g., separate correlations for prosocial behavior and empathic concern). The effect-size estimates were combined and averaged within study in order to provide an overall effect size estimate. By doing so, this technique retains as much data as possible without violating the independence assumption that underlies the validity of meta-analytic procedures. The analyses were conducted for prosocial media on the combined outcomes and then on each individual outcome. Analyses were conducted using a random effects model to assess the heterogeneity in various subsets of studies. This model enables the results of this study to be generalizable outside of the articles included in this meta-analysis (Borenstein, Hedges, Higgins, \& Rothstein, 2010; Hunter \& Schmidt, 1990).

Finally, an analysis was conducted to explore the possibility of publication bias (also called selection bias) or the idea that only studies with significant results are published and those with nonsignificant results are less likely to be published. To examine the potential of selection bias, we used the rank correlation test (Begg \& Mazumdar, 1994) and Egger's regression test (Egger, Davey Smith, Schneider, \& Minder, 1997).

\section{Results}

The current meta-analysis consisted of 72 studies in 54 papers. Collectively, there were 17,134 participants, ranging in age from preschool age to adulthood. Of these studies, 49 included a measure of prosocial behavior, 28 included a measure of aggressive behavior, and 22 included a measure of empathic concern. Table 1 provides a more detailed view of the studies in the meta-analysis.

Overall, 243 independent effect size estimates were available. In the following text, we report an overall effect size for prosocial media, and effect sizes for the three different outcomes (prosocial behavior, aggression, and empathic concern). Note that when the different outcomes were combined for analyses, aggressive behavior was recoded, with higher values indicating lower levels of aggression, consistent with the direction of the other outcomes. To increase power, moderator analyses (unless specific to prosocial behavior) were conducted on the combined analyses only.

\section{Overall Meta-Analytic Results for Prosocial Media}

The meta-analysis revealed a significant, positive relationship between viewing prosocial media and positive outcomes $(r=.18$, 95\% CI [.14-.21], $\left.p<.001, k=72 ; \mathrm{I}^{2}=72.50 ; \tau^{2}=.02\right)$. In terms of specific outcome, prosocial media was positively associated with prosocial behavior $\left(r_{+}=.16,95 \%\right.$ CI [.12-.20], $p<$ $\left..001, k=49 ; \mathrm{I}^{2}=77.47 ; \tau^{2}=.01\right)$, and empathic concern, $\left(r_{+}=\right.$ $.23,95 \%$ CI [.15-.30], $\left.p<.001, k=22 ; \mathrm{I}^{2}=86.12 ; \tau^{2}=.02\right)$, and negatively associated with aggressive behavior $\left(r_{+}=-.14\right.$,
95\% CI [.09-.19], $p<.001, k=28 ; \mathrm{I}^{2}=60.27 ; \tau^{2}=.01$ ). Additional analyses revealed that there were no significant differences in the strength of effect sizes between prosocial behavior, empathic concern, and aggression. Step-by-step removal of outliers in the combined sample did not reveal any substantial outlier effects in the dataset.

\section{Moderator Analyses for Combined Outcome Variables}

Substantial heterogeneity in the distribution of effect sizes suggested the need to explore for some moderation effects, $Q(71)=$ 258.16, $p<.001$. Not enough studies provided results separately for boys and girls; accordingly, sex of participant was not analyzed as a moderator.

Age of participant. Age significantly moderated the impact of viewing prosocial media, $Q(3)=20.66, p<.001$. Effects of prosocial media on positive outcomes were significantly associated with positive outcomes at every age in the analysis. Follow up analyses revealed that prosocial media had a stronger effect on positive outcomes in emerging adulthood $\left(r_{+}=.24,95 \% \mathrm{CI}\right.$ [.19-.29], $\left.p<.001, k=38 ; \mathrm{I}^{2}=57.30 ; \tau^{2}=.02\right)$, than in adolescence $\left(r_{+}=.08,95 \%\right.$ CI [.02-.14], $p<.01, k=13, \mathrm{I}^{2}=$ $\left.77.30 ; \tau^{2}=.01 ; p<.05\right), Q(1)=18.45, p<.001$, and adulthood $\left(r_{+}=.09,95 \%\right.$ CI [.02- .17], $p<.05, k=7 ; \mathrm{I}^{2}=13.28 ; \tau^{2}=$ $.01), Q(1)=11.04, p<.01$, but not in childhood $\left(r_{+}=.19,95 \%\right.$ CI [.09-.29], $\left.p<.001, k=15, \mathrm{I}^{2}=82.22 ; \tau^{2}=.03\right)$. Comparisons between all other groups did not result in differences in strength of effect sizes.

Region. Region significantly moderated the effect of prosocial media, $Q(2)=6.84, p<.05$. Though both were individually significant, studies from Europe $\left(r_{+}=.23,95 \%\right.$ CI [.17-.29], $p<$ $\left..001, k=39 ; \mathrm{I}^{2}=71.89 ; \tau^{2}=.03\right)$ showed a larger effect size than studies from North America $\left(r_{+}=.14,95 \%\right.$ CI [.08-.20], $p<$ $\left.\left..001, k=27 ; \mathrm{I}^{2}=71.72 ; \tau^{2}=.01\right), Q(1)=4.31, p<.05\right)$ and Asia $\left(r_{+}=.12,95 \%\right.$ CI [.04-.19], $p<.01, k=4$; $\mathrm{I}^{2}=72.99$; $\left.\tau^{2}=.01\right), Q(1)=5.63, p<.05$. This appeared to be an effect of the high number of studies coming out of the European Greitemeyer lab. Indeed, when Greitemeyer was controlled for, the effect of region became nonsignificant, $Q(2)=.11, p=.99$.

Media type. Media type showed significant heterogeneity within the results, with passive media $\left(r_{+}=.25,95 \%\right.$ CI $[.19-$ $\left..31], p<.001, k=35 ; \mathrm{I}^{2}=74.21 ; \tau^{2}=.02\right)$, showing a larger effect size than active media $\left(r_{+}=.13,95 \%\right.$ CI [.08-.17], $p<$ $\left..001, k=34 ; \mathrm{I}^{2}=67.41 ; \tau^{2}=.01\right), Q(1)=18.14, p<.001$, though notably, both were highly significant. Though much of the active media studies come from the Greitemeyer lab, controlling for this factor did not markedly change the results for media type.

Study design. Study design also significantly moderated the results, $Q(2)=21.80, p<.001$, though the effect of prosocial media on positive outcomes was significant regardless of methodology. Experimental studies showed a larger effect size $\left(r_{+}=.21\right.$, 95\% CI [.17-.25], $\left.p<.001, k=57 ; \mathrm{I}^{2}=57.25 ; \tau^{2}=.02\right)$ than did longitudinal $\left(r_{+}=.07,95 \%\right.$ CI [.01-.14], $p<.05, k=7 ; \mathrm{I}^{2}=$ 78.67; $\left.\tau^{2}=.01\right), Q(1)=11.91, p<.001$, and cross-sectional designs $\left(r_{+}=.12,95 \%\right.$ CI [.05-.18], $p<.01, k=13 ; \mathrm{I}^{2}=85.14$ $\left.\tau^{2}=.01\right), Q(1)=5.59, p<.05$. There was no difference in the strength of effect size between longitudinal and cross-sectional designs. 
Table 1

Effect Sizes, Standard Errors, Selected Moderators, and Sample Size for Included Studies

\begin{tabular}{|c|c|c|c|c|c|c|c|c|c|c|c|}
\hline Study & $N$ & $r, S E$ & Outcome & $\%$ Male & Age & Region & $\begin{array}{l}\text { Media } \\
\text { type }\end{array}$ & $\begin{array}{l}\text { Study } \\
\text { type }\end{array}$ & $\begin{array}{l}\text { Target of } \\
\text { PB }\end{array}$ & $\begin{array}{l}\text { Type of } \\
\text { PB }\end{array}$ & $\begin{array}{l}\text { Cost of } \\
\text { PB }\end{array}$ \\
\hline Abelman, 1985 & 286 & $.42, .05$ & PB & Unknown & $\mathrm{C}$ & $\mathrm{N}$ & TV & $\mathrm{C}$ & $\mathrm{Fr}$ & G & $\mathrm{L}$ \\
\hline Jin, 2011 & 136 & $\begin{array}{r}.50, .06 \\
-.20, .08 \\
-.19, .08\end{array}$ & EM, PB & $57 \%$ & $\mathrm{E}$ & $\mathrm{N}$ & VG & $\mathrm{E}$ & $\mathrm{U}$ & $\mathrm{V}, \mathrm{D}$ & $\mathrm{H}$ \\
\hline \multicolumn{12}{|l|}{ Atkins and } \\
\hline Greitemeyer, 2008 & 80 & $\begin{array}{l}.34, .10 \\
.57, .07 \\
.46, .08 \\
.54, .07\end{array}$ & EM, PB & Unknown & $\mathrm{E}$ & $\mathrm{Eu}$ & M & $\mathrm{E}$ & St & $\mathrm{H}$ & $\mathrm{L}$ \\
\hline Bankart and Anderson, 1979 & 22 & $\begin{array}{l}.42, .10 \\
.42, .10\end{array}$ & AG & $56 \%$ & $\mathrm{C}$ & $\mathrm{N}$ & $\mathrm{TV}$ & $\mathrm{E}$ & & & \\
\hline Böhm et al., 2016 & 381 & $\begin{array}{r}.15, .05 \\
-.07, .05\end{array}$ & AG & $48 \%$ & $\mathrm{E}$ & $\mathrm{E}$ & M & $\mathrm{E}$ & & & \\
\hline Chambers and Ascione, 1987 & 160 & $-.19, .12$ & PB & $50 \%$ & $\mathrm{C}$ & $\mathrm{N}$ & VG & $\mathrm{E}$ & St & $\mathrm{D}$ & $\mathrm{H}$ \\
\hline Coyne, Linder, et al., 2016 & 175 & $\begin{array}{r}.01, .08 \\
.03, .08 \\
.06, .08 \\
-.10, .11 \\
-.17, .11 \\
-.11, .11 \\
.11, .10 \\
.09, .10 \\
.11, .10 \\
.14, .08 \\
.18, .07 \\
.21, .07 \\
.12, .11 \\
.10, .11 \\
.14, .11 \\
.16, .10 \\
.20, .10 \\
.23, .10\end{array}$ & AG, PB & $46 \%$ & $\mathrm{C}$ & $\mathrm{N}$ & TV & $\mathrm{C}, \mathrm{L}$ & $\mathrm{U}$ & G & $\mathrm{L}$ \\
\hline Coyne et al., 2010 & 154 & $\begin{array}{r}-.16, .13 \\
-.09, .15 \\
-.11, .14 \\
.19, .13 \\
-.02, .13 \\
-.10, .15 \\
-.20, .13 \\
.02, .15 \\
.22, .13\end{array}$ & $\mathrm{~PB}, \mathrm{AG}$ & $50 \%$ & $\mathrm{E}$ & $\mathrm{N}$ & VG & $\mathrm{E}$ & $\mathrm{St}, \mathrm{Fr}, \mathrm{Fa}$ & $\mathrm{D}$ & $\mathrm{H}$ \\
\hline Coyne et al., 2010 & 154 & $\begin{array}{r}.05, .11 \\
-.01, .11 \\
.07, .11 \\
.08, .11 \\
-.09, .11 \\
-.04, .11 \\
.08, .11 \\
.13, .10\end{array}$ & PB & $50 \%$ & $\mathrm{E}$ & $\mathrm{N}$ & VG & $\mathrm{C}$ & $\mathrm{St}, \mathrm{Fr}, \mathrm{Fa}$ & G & $\mathrm{L}$ \\
\hline $\begin{array}{l}\text { Coyne and Padilla-Walker, } \\
2015\end{array}$ & 548 & $\begin{array}{l}.21, .04 \\
.16, .04 \\
.13, .04 \\
.08, .04\end{array}$ & $\mathrm{~PB}, \mathrm{AG}$ & $48 \%$ & A & $\mathrm{N}$ & M & $\mathrm{C}, \mathrm{L}$ & St & G & $\mathrm{L}$ \\
\hline Coyne, Jensen, et al., 2016 & 508 & $\begin{array}{r}-.03, .07 \\
.04, .05 \\
-.07, .07 \\
-.12, .05\end{array}$ & $\mathrm{~PB}, \mathrm{AG}$ & $48 \%$ & A & $\mathrm{N}$ & VG & $\mathrm{C}$ & $\mathrm{Fa}$ & G & $\mathrm{L}$ \\
\hline De Leeuw et al., 2015 & 372 & $.17, .08$ & PB & $44 \%$ & $\mathrm{C}$ & $\mathrm{Eu}$ & TV & $\mathrm{E}$ & St & $\mathrm{D}$ & $\mathrm{H}$ \\
\hline De Leeuw et al., 2017 & 113 & $\begin{array}{l}.20, .09 \\
.20, .09\end{array}$ & PB & $46 \%$ & $\mathrm{C}$ & $\mathrm{Eu}$ & $\mathrm{F}$ & $\mathrm{E}$ & $\mathrm{Fr}$ & $\mathrm{H}$ & $\mathrm{L}$ \\
\hline Farsides et al., 2013 & 85 & $.25, .10$ & PB & $43 \%$ & $\mathrm{~A}$ & $\mathrm{Eu}$ & $\mathrm{F}$ & $\mathrm{E}$ & St & $\mathrm{G}$ & $\mathrm{L}$ \\
\hline Farsides et al., 2013 & 29 & $\begin{array}{l}.40, .15 \\
.40, .15\end{array}$ & EM, PB & $26 \%$ & $\mathrm{E}$ & $\mathrm{Eu}$ & $\mathrm{F}$ & $\mathrm{E}$ & $\mathrm{U}$ & $\mathrm{H}$ & $\mathrm{L}$ \\
\hline
\end{tabular}


Table 1 (continued)

\begin{tabular}{|c|c|c|c|c|c|c|c|c|c|c|c|}
\hline Study & $N$ & $r, S E$ & Outcome & $\%$ Male & Age & Region & $\begin{array}{l}\text { Media } \\
\text { type }\end{array}$ & $\begin{array}{l}\text { Study } \\
\text { type }\end{array}$ & $\begin{array}{l}\text { Target of } \\
\text { PB }\end{array}$ & $\begin{array}{l}\text { Type of } \\
\text { PB }\end{array}$ & $\begin{array}{l}\text { Cost of } \\
\text { PB }\end{array}$ \\
\hline Friedrich-Cofer et al., 1979 & 141 & $\begin{array}{r}.30, .16 \\
-.13, .17 \\
.33, .15\end{array}$ & $\mathrm{~PB}, \mathrm{AG}$ & Unknown & $\mathrm{C}$ & $\mathrm{N}$ & TV & $\mathrm{E}$ & Fr & G & $\mathrm{L}$ \\
\hline Gentile et al., 2009 & 727 & $\begin{array}{l}.08, .04 \\
.01, .04 \\
.15, .04 \\
.16, .04 \\
.14, .04\end{array}$ & $\mathrm{~PB}, \mathrm{EM}, \mathrm{AG}$ & $73 \%$ & A & A & VG & $\mathrm{C}$ & $\mathrm{U}$ & G & $\mathrm{L}$ \\
\hline Gentile et al., 2009 & 1830 & $\begin{array}{l}.21, .03 \\
.18, .03\end{array}$ & PB & $50 \%$ & M & A & VG & $\mathrm{L}, \mathrm{C}$ & $\mathrm{U}$ & G & $\mathrm{L}$ \\
\hline Gentile et al., 2009 & 161 & $\begin{array}{r}.12, .04 \\
-.04, .04 \\
.12, .04 \\
.08, .04 \\
.12, .04\end{array}$ & $\mathrm{~PB}$ & $41 \%$ & $\mathrm{E}$ & $\mathrm{N}$ & VG & $\mathrm{L}$ & St & $\mathrm{H}$ & $\mathrm{L}$ \\
\hline $\begin{array}{l}\text { Greitemeyer and Osswald, } \\
2008\end{array}$ & 38 & $.26, .15$ & PB & Unknown & $\mathrm{E}$ & $\mathrm{Eu}$ & VG & E & St & $\mathrm{H}$ & $\mathrm{H}$ \\
\hline Greitemeyer, 2009 & 33 & $.45, .13$ & PB & $52 \%$ & $\mathrm{E}$ & $\mathrm{Eu}$ & $\mathrm{M}$ & $\mathrm{E}$ & St & $\mathrm{H}$ & $\mathrm{L}$ \\
\hline Greitemeyer, 2009 & 50 & $\begin{array}{l}.65, .07 \\
.34, .12\end{array}$ & PB & Unknown & $\mathrm{E}$ & $\mathrm{Eu}$ & M & $\mathrm{E}$ & St & $\mathrm{T}$ & $\mathrm{H}$ \\
\hline Greitemeyer, 2009 & 59 & $\begin{array}{l}.26, .12 \\
.32, .11\end{array}$ & EM, PB & $19 \%$ & $\mathrm{E}$ & $\mathrm{Eu}$ & M & $\mathrm{E}$ & St & $\mathrm{D}$ & $\mathrm{H}$ \\
\hline Greitemeyer, 2009 & 48 & $\begin{array}{l}.48, .11 \\
.36, .12 \\
.32, .13\end{array}$ & $\mathrm{~PB}, \mathrm{EM}$ & $34 \%$ & $\mathrm{E}$ & $\mathrm{Eu}$ & M & $\mathrm{E}$ & St & $\mathrm{T}, \mathrm{D}$ & $\mathrm{L}, \mathrm{H}$ \\
\hline Greitemeyer, 2009 & 33 & $.34, .15$ & $\mathrm{~PB}$ & $52 \%$ & $\mathrm{E}$ & $\mathrm{Eu}$ & M & $\mathrm{E}$ & $\mathrm{U}$ & $\mathrm{T}$ & $\mathrm{L}$ \\
\hline Greitemeyer, 2009 & 50 & $.38, .13$ & EM & Unknown & $\mathrm{E}$ & $\mathrm{Eu}$ & M & $\mathrm{E}$ & & & \\
\hline Greitemeyer, 2009 & 90 & $.23, .10$ & PB & $18.6 \%$ & $\mathrm{E}$ & $\mathrm{Eu}$ & M & E & St & $\mathrm{D}$ & $\mathrm{H}$ \\
\hline $\begin{array}{l}\text { Greitemeyer and Osswald, } \\
2009\end{array}$ & 48 & $\begin{array}{l}.41, .13 \\
.58, .01 \\
.40, .13\end{array}$ & AG & $27 \%$ & $\mathrm{E}$ & $\mathrm{Eu}$ & VG & $\mathrm{E}$ & - & - & - \\
\hline $\begin{array}{l}\text { Greitemeyer and Osswald, } \\
2010\end{array}$ & 40 & $.35, .13$ & $\mathrm{~PB}$ & $36 \%$ & $\mathrm{E}$ & $\mathrm{Eu}$ & VG & E & St & $\mathrm{V}$ & $\mathrm{H}$ \\
\hline $\begin{array}{l}\text { Greitemeyer and Osswald, } \\
2010\end{array}$ & 37 & $\begin{array}{l}.58, .01 \\
.40, .13 \\
.60, .11\end{array}$ & PB & $27 \%$ & $\mathrm{E}$ & $\mathrm{Eu}$ & VG & $\mathrm{E}$ & St & $\mathrm{H}$ & $\mathrm{L}$ \\
\hline $\begin{array}{l}\text { Greitemeyer, Osswald, and } \\
\text { Brauer, } 2010 \\
\text { Greitemever, Osswald, and }\end{array}$ & 39 & $.34, .14$ & EM & $50 \%$ & $\mathrm{E}$ & $\mathrm{Eu}$ & VG & $\mathrm{E}$ & & & \\
\hline $\begin{array}{l}\text { Greitemeyer, Osswald, and } \\
\text { Brauer, } 2010\end{array}$ & 56 & 37.11 & EM & $36 \%$ & & & & & & & \\
\hline $\begin{array}{l}\text { Brauer, 2010 } \\
\text { Greitemeyer, } 2011\end{array}$ & 59 & $.31, .12$ & AG & $58 \%$ & $\begin{array}{l}\mathrm{E} \\
\mathrm{E}\end{array}$ & $\begin{array}{l}\mathrm{Eu} \\
\mathrm{Eu}\end{array}$ & $\begin{array}{l}V G \\
M\end{array}$ & $\begin{array}{l}\mathrm{E} \\
\mathrm{E}\end{array}$ & & & \\
\hline Greitemeyer, 2011 & 38 & $\begin{array}{r}.40, .13 \\
.47, .12 \\
-.02, .16 \\
-.12, .16\end{array}$ & AG & $13 \%$ & $\mathrm{E}$ & $\mathrm{Eu}$ & M & $\mathrm{E}$ & & & \\
\hline Greitemeyer, 2011 & 80 & $\begin{array}{l}.42, .09 \\
.31, .10\end{array}$ & $\mathrm{AG}$ & $48 \%$ & $\mathrm{E}$ & $\mathrm{Eu}$ & M & $\mathrm{E}$ & & & \\
\hline Greitemeyer, 2011 & 90 & $.22, .10$ & AG & $13 \%$ & $\mathrm{E}$ & $\mathrm{Eu}$ & M & $\mathrm{E}$ & & & \\
\hline Greitemeyer, 2011 & 50 & $\begin{array}{l}.41, .12 \\
.43, .11 \\
.37, .12 \\
.13, .14 \\
.33, .13 \\
.36, .12\end{array}$ & $\mathrm{AG}$ & $52 \%$ & Ad & $\mathrm{Eu}$ & M & $\mathrm{E}$ & & & \\
\hline Greitemeyer, 2011 & 97 & $.30, .13$ & $\mathrm{~PB}$ & $49 \%$ & Ad & $\mathrm{Eu}$ & VG & $\mathrm{E}$ & $\mathrm{U}$ & $\mathrm{T}$ & $\mathrm{L}$ \\
\hline Greitemeyer, 2011 & 41 & $.00, .16$ & AG & Unknown & $\mathrm{Ad}$ & $\mathrm{Eu}$ & VG & $\mathrm{E}$ & & & \\
\hline Greitemeyer et al., 2012 & 65 & $\begin{array}{l}.31, .14 \\
.54, .10\end{array}$ & $\mathrm{AG}$ & $48 \%$ & $\mathrm{E}$ & $\mathrm{Eu}$ & VG & $\mathrm{E}$ & & & \\
\hline Greitemeyer et al., 2012 & 58 & $\begin{array}{r}-.52, .09 \\
.35, .11 \\
.61, .08 \\
.58, .08\end{array}$ & $\mathrm{AG}$ & $40 \%$ & $\mathrm{E}$ & $\mathrm{Eu}$ & VG & $\mathrm{E}$ & & & \\
\hline $\begin{array}{l}\text { Hackenberg and } \\
\text { Greitemeyer, } 2015\end{array}$ & 248 & $\begin{array}{r}-.01, .06 \\
.16, .06\end{array}$ & EM, PB & Unknown & $\mathrm{Ad}$ & $\mathrm{Eu}$ & VG & $\mathrm{E}$ & St & $\mathrm{H}$ & $\mathrm{H}$ \\
\hline $\begin{array}{l}\text { Harrington and O'Connell, } \\
2016\end{array}$ & 538 & $\begin{array}{l}-.10, .04 \\
-.11, .04\end{array}$ & $\mathrm{~PB}, \mathrm{EM}$ & $59 \%$ & Ad & $\mathrm{Eu}$ & VG & $\mathrm{C}$ & $\mathrm{U}$ & $\mathrm{H}, \mathrm{S}$ & $\mathrm{L}, \mathrm{G}$ \\
\hline
\end{tabular}


Table 1 (continued)

\begin{tabular}{|c|c|c|c|c|c|c|c|c|c|c|c|}
\hline Study & $N$ & $r, S E$ & Outcome & $\%$ Male & Age & Region & $\begin{array}{l}\text { Media } \\
\text { type }\end{array}$ & $\begin{array}{l}\text { Study } \\
\text { type }\end{array}$ & $\begin{array}{l}\text { Target of } \\
\text { PB }\end{array}$ & $\begin{array}{l}\text { Type of } \\
\text { PB }\end{array}$ & $\begin{array}{l}\text { Cost of } \\
\text { PB }\end{array}$ \\
\hline Horne, 2011 & 120 & $\begin{array}{r}-.07, .04 \\
-.11, .04 \\
.35, .15 \\
.35, .15 \\
.35, .15 \\
.35, .15\end{array}$ & EM & $60 \%$ & E & $\mathrm{N}$ & VG & $\mathrm{E}$ & & & \\
\hline $\begin{array}{l}\text { Indlekofer and Greitemeyer, } \\
2012\end{array}$ & 152 & $\begin{array}{l}-.08, .08 \\
-.07, .08\end{array}$ & $\mathrm{EM}$ & Unknown & A & Eu & VG & $\mathrm{E}$ & & & \\
\hline Kim and Kim, 2008 & 132 & $\begin{array}{l}.36, .13 \\
.27, .14\end{array}$ & EM & $42 \%$ & $\mathrm{E}$ & $\mathrm{N}$ & TV & $\mathrm{E}$ & & & \\
\hline Liu, et al., 2015 & 49 & $\begin{array}{r}.28, .13 \\
-.16, .14\end{array}$ & $\mathrm{AG}$ & $49 \%$ & $\mathrm{E}$ & A & VG & $\mathrm{E}$ & & & \\
\hline Möck and Greitemeyer, 2014 & 97 & $\begin{array}{l}.16, .10 \\
.28, .09\end{array}$ & EM, PB & Unknown & $\mathrm{E}$ & $\mathrm{Eu}$ & $\mathrm{F}$ & $\mathrm{E}$ & $\mathrm{U}$ & $\mathrm{H}$ & $\mathrm{H}$ \\
\hline $\begin{array}{l}\text { Nitzsche and Greitemeyer, } \\
2012\end{array}$ & 41 & $\begin{array}{r}-.28, .14 \\
.20, .15\end{array}$ & EM & Unknown & $\mathrm{E}$ & $\mathrm{Eu}$ & M & $\mathrm{E}$ & & & \\
\hline Niven, 2015 & 25 & $\begin{array}{r}-.20, .10 \\
.20, .10\end{array}$ & AG & $24 \%$ & Ad & $\mathrm{Eu}$ & M & $\mathrm{E}$ & & & \\
\hline Padilla-Walker et al., 2015 & 441 & $\begin{array}{r}.00, .05 \\
.01, .05 \\
.08, .05 \\
.08, .05 \\
.09, .05 \\
-.08, .05 \\
.05, .05 \\
.01, .05 \\
.03, .05 \\
.09, .05 \\
.08, .05 \\
.02, .05 \\
.07, .05 \\
.01, .05\end{array}$ & $\mathrm{~PB}, \mathrm{AG}$ & $48 \%$ & A & $\mathrm{N}$ & TV & $\mathrm{C}, \mathrm{L}$ & $\mathrm{Fa}, \mathrm{Fr}, \mathrm{St}$ & G & $\mathrm{L}$ \\
\hline Petikas, 2013 & 30 & $\begin{array}{l}.29, .16 \\
.16, .17 \\
.02, .18 \\
.11, .18\end{array}$ & AG, PB & $50 \%$ & $\mathrm{E}$ & $\mathrm{N}$ & VG & $\mathrm{E}$ & St & $\mathrm{H}$ & $\mathrm{L}$ \\
\hline Pieschl and Fegers, 2015 & 60 & $.34, .11$ & AG & Unknown & $\mathrm{E}$ & $\mathrm{Eu}$ & M & $\mathrm{C}$ & & & \\
\hline Prot et al., 2014 & 2,202 & $\begin{array}{l}.25, .02 \\
.07, .02\end{array}$ & EM & $40 \%$ & $\mathrm{E}$ & M & $\mathrm{C}$ & $\mathrm{C}$ & & & \\
\hline Prot et al., 2014 & 3,034 & $\begin{array}{c}.10, .02 \\
.09, .02 \\
.02, .02 \\
.08, .02 \\
.05, .02 \\
.02, .02 \\
.08, .02 \\
.09, .02 \\
.06, .02 \\
.01, .02 \\
-.04, .02 \\
.0, .02\end{array}$ & EM, PB & $73 \%$ & A & A & VG & $\mathrm{C}, \mathrm{L}$ & $\mathrm{U}$ & $\mathrm{H}$ & $\mathrm{L}$ \\
\hline Rosenberg et al., 2013 & 60 & $\begin{array}{r}.04, .18 \\
-.04, .18 \\
.08, .18 \\
.16, .18\end{array}$ & PB & $50 \%$ & $\mathrm{E}$ & $\mathrm{N}$ & $\mathrm{C}$ & $\mathrm{E}$ & St & $\mathrm{H}$ & $\mathrm{L}$ \\
\hline Rosenkoetter, 1999 & 29 & $\begin{array}{l}.63, .18 \\
.18, .31 \\
.48, .22 \\
.11, .22\end{array}$ & PB & Unknown & $\mathrm{C}$ & $\mathrm{N}$ & TV & $\mathrm{E}$ & St & $\mathrm{G}$ & $\mathrm{L}$ \\
\hline Rosenkoetter, 1999 & 34 & $.21, .15$ & PB & Unknown & $\mathrm{C}$ & $\mathrm{N}$ & TV & $\mathrm{E}$ & St & $\mathrm{G}$ & $\mathrm{L}$ \\
\hline Ruth, 2017 & 256 & $\begin{array}{r}.12, .06 \\
-.00, .06\end{array}$ & PB & $34 \%$ & Ad & $\mathrm{E}$ & M & $\mathrm{E}$ & St & $\mathrm{D}$ & $\mathrm{H}$ \\
\hline Saleem et al., 2012 & 330 & $\begin{array}{l}.32, .06 \\
.16, .07 \\
.27, .06 \\
.14, .07\end{array}$ & AG, PB & $68 \%$ & $\mathrm{E}$ & $\mathrm{N}$ & VG & $\mathrm{E}$ & $\mathrm{U}$ & $\mathrm{G}$ & $\mathrm{L}$ \\
\hline
\end{tabular}


Table 1 (continued)

\begin{tabular}{|c|c|c|c|c|c|c|c|c|c|c|c|}
\hline Study & $N$ & $r, S E$ & Outcome & $\%$ Male & Age & Region & $\begin{array}{l}\text { Media } \\
\text { type }\end{array}$ & $\begin{array}{l}\text { Study } \\
\text { type }\end{array}$ & $\begin{array}{l}\text { Target of } \\
\text { PB }\end{array}$ & $\begin{array}{l}\text { Type of } \\
\text { PB }\end{array}$ & $\begin{array}{l}\text { Cost of } \\
\text { PB }\end{array}$ \\
\hline & & $\begin{array}{l}.28, .06 \\
.17, .07 \\
.31, .06 \\
.12, .07\end{array}$ & & & & & & & & & \\
\hline Saleem et al., 2012 & 127 & $\begin{array}{l}.20, .08 \\
.13, .09\end{array}$ & AG, PB & $54 \%$ & Ad & $\mathrm{N}$ & VG & $\mathrm{E}$ & St & $\mathrm{H}$ & $\mathrm{L}$ \\
\hline $\begin{array}{l}\text { Schmid and Greitemeyer, } \\
2015\end{array}$ & 88 & $\begin{array}{l}.00, .11 \\
.17, .10\end{array}$ & EM, PB & Unknown & Ad & $\mathrm{Eu}$ & VG & $\mathrm{E}$ & St & $\mathrm{H}$ & $\mathrm{H}$ \\
\hline Smith, 2015 & 169 & $\begin{array}{r}-.13, .08 \\
.00, .09 \\
-.06, .09 \\
-.16, .11 \\
.03, .13 \\
-.02, .13 \\
-.10, .11 \\
-.04, .12 \\
-.10, .12 \\
.22, .07 \\
.10, .08 \\
.10, .09 \\
.24, .10 \\
.23, .12 \\
.23, .13 \\
.22, .11 \\
-.02, .12 \\
-.01, .12\end{array}$ & $\mathrm{~PB}, \mathrm{AG}$ & $50 \%$ & $\mathrm{C}$ & $\mathrm{N}$ & VG & $\mathrm{C}, \mathrm{L}$ & $\mathrm{U}$ & G & $\mathrm{L}$ \\
\hline Sprafkin et al., 1975 & 30 & $\begin{array}{l}.55, .20 \\
.55, .20 \\
.66, .20 \\
.66, .20\end{array}$ & PB & $50 \%$ & $\mathrm{C}$ & $\mathrm{N}$ & $\mathrm{TV}$ & $\mathrm{E}$ & St & $\mathrm{H}$ & $\mathrm{L}$ \\
\hline Tamborini et al., 2012 & 100 & $.25, .09$ & PB & $37 \%$ & $\mathrm{E}$ & $\mathrm{N}$ & TV & $\mathrm{E}$ & $\mathrm{U}$ & $\mathrm{T}$ & $\mathrm{L}$ \\
\hline Teachman and Orme, 1981 & 120 & $\begin{array}{r}-.01, .16 \\
.14, .15 \\
.08, .16 \\
.42, .13\end{array}$ & $\mathrm{~PB}$ & $50 \%$ & $\mathrm{C}$ & $\mathrm{N}$ & TV & $\mathrm{E}$ & St & $\mathrm{D}$ & $\mathrm{H}$ \\
\hline Toeplitz-Winiewska, 1977 & 152 & $\begin{array}{l}.06, .06 \\
.31, .05\end{array}$ & $\mathrm{AG}$ & Unknown & A & $\mathrm{Eu}$ & $\mathrm{F}$ & $\mathrm{E}$ & & & \\
\hline Tsai and Kaufman, 2009 & 51 & $\begin{array}{l}.25, .13 \\
.31, .13 \\
.31, .12 \\
.22, .13\end{array}$ & EM, PB & $51 \%$ & $\mathrm{C}$ & $\mathrm{N}$ & VG & $\mathrm{E}$ & U & G & $\mathrm{L}$ \\
\hline $\begin{array}{l}\text { Tsay-Vogel and Krakowiak, } \\
2016\end{array}$ & 143 & $.06, .08$ & $\mathrm{~PB}$ & $19.6 \%$ & $\mathrm{E}$ & $\mathrm{N}$ & $\mathrm{TV}$ & E & $\mathrm{U}$ & G & $\mathrm{L}$ \\
\hline $\begin{array}{l}\text { Ullrich and Greitemeyer, } \\
2011\end{array}$ & 91 & $\begin{array}{l}-.04, .11 \\
-.10, .10 \\
-.04, .11\end{array}$ & EM, PB & Unknown & A & $\mathrm{Eu}$ & VG & $\mathrm{E}$ & $\mathrm{U}$ & $\mathrm{H}$ & $\mathrm{H}$ \\
\hline Vieira, 2014 & 145 & $\begin{array}{r}-.07, .08 \\
.02, .08 \\
.00, .08 \\
.23, .08 \\
.75, .04 \\
.17, .08\end{array}$ & $\mathrm{EM}, \mathrm{AG}$ & $0 \%$ & A & M & VG & $\mathrm{C}$ & & & \\
\hline Woolf, 2009 & 1,882 & $\begin{array}{r}.03, .02 \\
-.01, .03\end{array}$ & $\mathrm{~PB}$ & $49 \%$ & $\mathrm{C}$ & $\mathrm{N}$ & TV & $\mathrm{C}$ & $\mathrm{U}$ & $\mathrm{G}$ & $\mathrm{L}$ \\
\hline
\end{tabular}

Note. $\quad$ Data for other variables can be obtained from the corresponding author. $\mathrm{PB}=$ prosocial behavior; $\mathrm{AG}=$ aggression; $\mathrm{EM}=$ empathic concern; Age: $\mathrm{C}=$ childhood; $\mathrm{A}=$ adolescence; $\mathrm{E}=$ emerging adulthood; $\mathrm{Ad}=$ adult; $\mathrm{M}=$ multiple; Region: $\mathrm{N}=$ North America; $\mathrm{Eu}=\mathrm{Europe} ; \mathrm{A}=\mathrm{Asia} ; \mathrm{M}=$ Multiple; Media type: TV = television; VG = video game; $\mathrm{M}=$ music; $\mathrm{F}=$ Film/Video; $\mathrm{C}=$ combined; Study type: $\mathrm{E}=$ experimental; $\mathrm{L}=1$ longitudinal; $\mathrm{C}=$ cross-sectional; Target of $\mathrm{PB}: \mathrm{Fr}=$ Friend; $\mathrm{Fa}=$ Family; $\mathrm{St}=$ Stranger; $\mathrm{U}=$ unknown; Type of $\mathrm{PB}: \mathrm{H}=$ helping; $\mathrm{S}=$ sharing; $\mathrm{D}=$ donating; $\mathrm{V}=$ volunteering; $\mathrm{T}=$ prosocial thoughts; $\mathrm{G}=$ general measure of prosocial behavior; Cost of $\mathrm{PB}$ : $\mathrm{L}=$ low cost; $\mathrm{H}=$ high cost. 
Funnel Plot of Standard Error by Fisher's Z

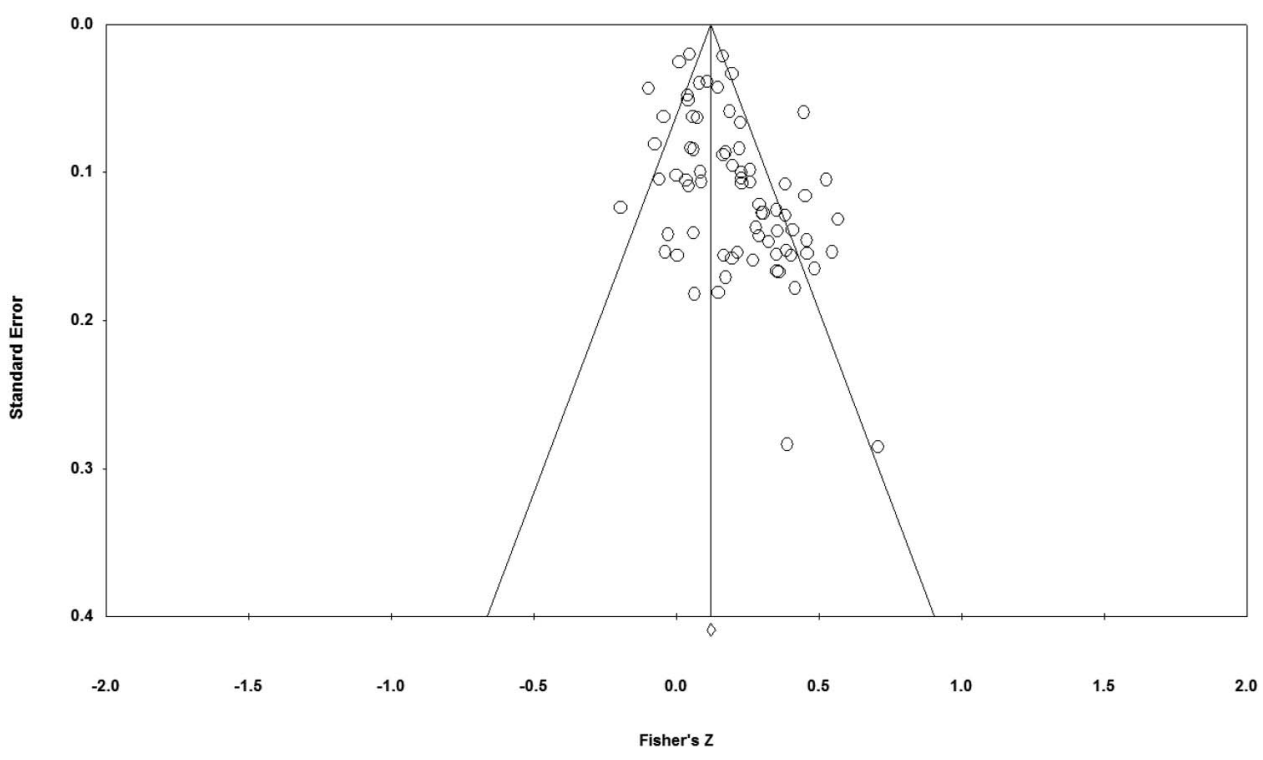

Figure 2. Funnel plot of standard error by Fisher's $z$.

Other study characteristics. Finally, we ran two different moderator analyses based on the publication status and author. Though both were significant, published studies showed a significantly larger effect size $\left(r_{+}=.20,95 \%\right.$ CI [.16-.24], $p<.001, k=55)$ than unpublished studies $\left(r_{+}=.11,95 \% \mathrm{CI}\right.$ [.04-.18], $p<.01, k=17), Q=4.41, p<.05$. Additionally, analyses revealed that Dr. Greitemeyer and colleagues' findings $\left(r_{+}=.27,95 \%\right.$ CI [.20-.34], $\left.p<.001, k=29\right)$ were significantly larger than findings coming from the rest of the field $\left(r_{+}=.13\right.$, 95\% CI [.09-.17], $p<.001, k=43), Q=11.78, p<.001$, though notably, both were highly significant.

\section{Moderator Analyses for Prosocial Behavior Outcomes Only}

Target. Target of prosocial behavior moderated the results, $Q(2)=26.86, p<.001$. Indeed, prosocial media only had a significant effect on prosocial behavior aimed at strangers and not directed toward family or friends. The results revealed that prosocial media had a larger effect on strangers $\left(r_{+}=.19,95 \% \mathrm{CI}\right.$ [.13-.25], $\left.p<.001, k=27 ; \mathrm{I}^{2}=61.36 ; \tau^{2}=.01\right)$, than family $\left(r_{+}=.02,95 \%\right.$ CI [-.02-.06], $\left.p=.42, k=5 ; \mathrm{I}^{2}=0.00 ; \tau^{2}=.00\right)$, $Q(1)=27.70, p<.001$, but not friends $\left(r_{+}=.15,95 \% \mathrm{CI}\right.$ [-.02-.32], $\left.p=.08, k=6 ; \mathrm{I}^{2}=83.24 ; \tau^{2}=.04\right), Q(1)=.53, p=$ .46 . There was no significant difference between prosocial behavior toward family and friends.

Type of prosocial behavior. Prosocial media had a significant effect on helping behaviors $\left(r_{+}=.18,95 \%\right.$ CI [.11-.25], $p<$ $\left..001, k=18 ; \mathrm{I}^{2}=77.90 ; \tau^{2}=.02\right)$ and prosocial thinking $\left(r_{+}=\right.$ $.34,95 \%$ CI [.24-.44], $\left.p<.001, k=5 ; \mathrm{I}^{2}=0.00 ; \tau^{2}=.00\right)$, but not on donating $\left(r_{+}=.09,95 \%\right.$ CI $[-.04-.21], p=.16, k=9$; $\left.\mathrm{I}^{2}=69.33 ; \tau^{2}=.02\right)$, sharing $\left(r_{+}=.04,95 \%\right.$ CI [-.17-.24], $p=$ $\left..72, k=2 ; \mathrm{I}^{2}=92.71 ; \tau^{2}=.02\right)$, or volunteering $\left(r_{+}=.08,95 \%\right.$ CI [-.46-.57], $\left.p=.79, k=2 ; \mathrm{I}^{2}=91.18 ; \tau^{2}=.16\right)$, though these last two should be viewed with caution because of the low number of studies. There were no studies that examined the effect of prosocial media on emotional support, accordingly, these analyses are not conducted.

Cost of prosocial behavior. Prosocial media influenced both low-cost $\left(r_{+}=.17,95 \%\right.$ CI [.12-.22], $p<.001, k=34 ; \mathrm{I}^{2}=$ 80.75; $\left.\tau^{2}=.02\right)$ and high-cost $\left(r_{+}=.13,95 \%\right.$ CI [.04-.22], $p<$ $\left..01, k=15 ; \mathrm{I}^{2}=63.59 ; \tau^{2}=.02\right)$ prosocial behaviors. There was no significant difference in effect size between the two categories.

\section{Publication Bias}

A number of different tests were conducted to analyze potential publication bias in the analyses. Formal publication bias tests revealed some publication bias in some tests, but not others. These should be viewed with caution as nearly all publication bias tests assume a single population of effects (Johnson \& Eagly, 2014), while the current analysis consists of a random effects model. An examination of the funnel plot for the combined outcomes resulted in a largely symmetric funnel plot with few outliers, suggesting that the finding is robust (see Figure 2). Additionally, both the rank correlation test and Egger's regression test, respectively, were significant for prosocial behavior $(z=2.26, p<.05$; $t=3.74, p<$ $.001)$ and aggression $(z=1.99, p<.05 ; t=2.40, p<.05)$, but not for empathic concern $(z=1.30, p=.19 ; t=1.40, p=.18)$. Overall, these analyses suggest that the findings are robust, and publication bias in the field, though present, is moderate.

\section{Discussion}

The current study sought to extend existing meta-analyses on the effects of prosocial media in three different ways. First, we sought to examine media more holistically rather than just considering one medium, such as video games. Second, we considered 
three separate outcomes of prosocial media content: prosocial behavior, empathic concern, and aggression. Finally, we considered prosocial behavior and moderators in a multidimensional fashion, consistent with the developmental literature on prosocial behavior. Overall findings were consistent with past metaanalyses, and suggested a clear direction for future research in this area considering the gaps where there was not strong enough power to detect meaningful moderation.

\section{Overall Effects of Prosocial Media Content}

More specifically, across the 72 studies, 17,134 participants and 243 unique effect sizes were assessed, and findings suggested that prosocial media was positively associated with prosocial behavior and empathic concern and negatively associated with aggression. This finding also contributes to a growing body of research suggesting that prosocial media is not only associated with more positive outcomes, but also with fewer negative outcomes (e.g., Greitemeyer \& Mügge, 2014; Padilla-Walker, Coyne, et al., 2015). The results from the meta-analysis were fairly consistent, with prosocial media being associated with positive outcomes for different types of media, using various methodologies, in different countries, and across multiple ages. These results confirm the general learning model and suggest that the effect of viewing prosocial media is robust across multiple contexts. Effect sizes were comparable to those found in other studies looking at general prosocial behavior (e.g., Greitemeyer \& Mügge, 2014; Mares \& Woodard, 2005), and Table 2 shows how prosocial media compares with other recent meta-analyses of media effects. However, there were a few notable moderators to these effects that are discussed in the following section.

\section{Moderators}

A number of significant moderators emerged when examining the wider impact of prosocial media on outcomes. More specifically, there was significant moderation regarding age, suggesting that prosocial effects were stronger for emerging adults than for adolescents and adults. This finding is somewhat perplexing and certainly necessities further research, but may be a function of the types or frequency of media used during emerging adulthood (Coyne et al., 2013) or the family or social changes that take place during this developmental time period that might also involve media use (Arnett, 2000). Some studies have also found that prosocial behavior dips during adolescence and then rebounds into late adolescence and emerging adulthood (e.g., Carlo, Crockett, Randall, \& Roesch, 2007), which might account for stronger associations between media content and prosocial behavior during emerging adulthood. It is of note, however, that there were substantially more studies done with emerging adults than with adolescents or adults. This was surprising, as prosocial media is common in popular adolescent TV programs and movies (Coyne $\&$ Smith, 2014), and is likely due to the ease of obtaining emerging adult college samples (indeed, in the current study, $88 \%$ of studies focusing on emerging adults consisted of college students, with the other $12 \%$ not specifying). Though emerging adulthood is an important time to study media effects (see Coyne et al., 2013), prosocial media may have a longer term impact on the development of prosocial behavior, empathic concern, and aggression during childhood and adolescence. This is certainly the case for the impact of media violence on the development of aggressive behavior (Bushman \& Huesmann, 2006). There are very few longitudinal studies of the effects of prosocial media, none begin in early childhood, and none are more than a few years in length. We encourage researchers to specifically examine the long-term effects of exposure to prosocial media across all stages of development.

Region also moderated the effects, though notably, prosocial media showed significant positive effects across all regions examined in the current study. Our analyses suggested that prosocial media tended to have the strongest effects when studied in an experimental context, which may also explain the region findings. These findings suggest that prosocial media has a stronger immediate impact on behavior as opposed to a lengthier effect. Again, there were very few longitudinal studies, so we call for more research to be conducted using this methodology (and in multiple regions) to confirm these results. Additionally, effect sizes were larger when coming from Dr. Greitemeyer's lab as compared to other researchers, likely a result of the high number of experimental studies and lower sample sizes that are typical of his research.

Effects of prosocial media were also stronger for passive media (e.g., TV, movies) than active media (e.g., video games, virtual reality). This went against expectations as we hypothesized that

Table 2

Comparisons With Recent Meta-Analyses of Media Effects

\begin{tabular}{llcl}
\hline \multicolumn{1}{c}{ Media type } & \multicolumn{1}{c}{ Outcome } & Effect size & \multicolumn{1}{c}{ Reference } \\
\hline Texting & Driving reaction time & -.57 & Caird et al. (2014) \\
Advertising of sex and violence & Memory for ads & $-.19^{\mathrm{a}}$ & Lull and Bushman (2015) \\
Media violence & Aggressive behavior & .19 & Greitemeyer and Mügge (2014) \\
Prosocial media & Positive outcomes & .18 & Current meta-analysis \\
Facebook use & Loneliness & .17 & Song et al. (2014) \\
Thin-ideal body image in media & Body dissatisfaction & $-.14^{\mathrm{a}}$ & Grabe et al. (2008) \\
Educational media (Sesame Street) & Educational outcomes & $.14^{\mathrm{a}}$ & Mares and Pan (2013) \\
Media use & ADHD-related behaviors & .12 & Nikkelen et al. (2014) \\
Television viewing & Body fatness & .07 & Marshall et al. (2004) \\
\hline
\end{tabular}

Note. Rosenthal's (1994) formula for converting between $r$ and $d$ was used to standardize scores where appropriate. ADHD = attention-deficit/hyperactivity disorder.

${ }^{a}$ Effect sizes originally reported as $d$ were standardized and reported as $r$ to make meaningful comparisons across studies. 
active media represents a more immersive experience for the consumer and would be more likely to result in learning of the modeled behavior. One speculation is that prosocial messages are stronger and more consistent in passive media (Coyne \& Smith, 2014). Though such behavior does exist in active media such as video games, true portrayals of "pure" prosocial behavior may be somewhat rare and certainly not as popular as violent video games. Accordingly, participants may have had more experience with prosocial behavior in passive media and consequently this medium may be having a larger impact on behavior.

\section{Prosocial Behavior as a Multidimensional Construct}

One major aim of the study was to examine prosocial behavior in the media in a multidimensional context to reflect how it is being increasingly measured in the prosocial literature. Exposure to prosocial media showed a significant effect on prosocial behavior aimed toward strangers, but not toward family or friends. Prosocial behavior is considerably more common toward family and friends than toward strangers (Padilla-Walker \& Christensen, 2011), so it is interesting that prosocial media did not transfer to positive behavior in these relationships, especially given that prosocial behavior is more commonly portrayed in the media in a friend or family context than among strangers (Padilla-Walker et al., 2013). However, this finding is consistent with another study that found aggressive content to be longitudinally associated with prosocial behavior toward strangers but not toward other targets (Padilla-Walker et al., 2015), suggesting this may be a meaningful pattern. One possible explanation is that prosocial behavior toward strangers is more often promoted by dispositional traits such as empathic concern and self-regulation, whereas prosocial behavior toward family members and friends is more a function of the quality of the relationship with that person (Padilla-Walker \& Christensen, 2011). Thus, it may be more likely that prosocial media content is related to increases in empathic concern (indeed, the current results suggest this association exists) rather than changes in relationships. However, it should also be noted that relatively few studies considered prosocial behavior toward family or friends, so future research should continue to explore target of behavior, both as it is presented in the media, and as measured in developmental outcomes.

Additionally, exposure to prosocial media was more likely to influence certain types of prosocial behavior, such as helping others and having prosocial thoughts, while not influencing more specific behaviors, such as volunteering or donating. One possible explanation is the type of prosocial acts portrayed in the media may have some impact on the type of behavior modeled (i.e., direct imitation). For example, perhaps helping behaviors are more often portrayed in the media than are donating behaviors. However, there were not enough studies that specified different types of prosocial behavior in the media for us to assess this possibility. Another possibility is that prosocial content does not influence high cost behaviors (e.g., volunteering and donating) as much as it does low cost behavior, though that was not supported by examining cost as a moderator, which suggested no difference between high- and low-cost behavior. Clearly future research is needed to understand these distinctions, but these findings provide interesting insight suggesting that prosocial media content influences some types of prosocial behavior, and not others, which will be important for future research to continue to explore in a multidimensional fashion.

\section{Limitations and Conclusions}

There are a number of strengths to the current analysis, including the focus on multidimensionality of prosocial behavior, the large number of unpublished studies we were able to obtain, the use of multiple coders, and the effort to obtain zero order correlations from authors (see Rothstein \& Bushman, 2015). However, there are also notable limitations. The largest limitation of the meta-analysis was that there appeared to be some evidence of publication bias in the field. For example, though both were highly significant, unpublished papers showed a smaller effect than published articles. Accordingly, we encourage researchers to continue to research this topic to understand the wider impact of prosocial behavior. Though not a direct limitation, there were a number of moderators that could not be considered due to small sample sizes, but this provides important avenues for future research. In addition, future studies should consider prosocial content from additional types of media such as books and new media (e.g., social networking) and how this content might influence prosocial development.

Despite these limitations, the current study adds to research done over a decade ago (Mares \& Woodard, 2005) and more recently (Greitemeyer \& Mügge, 2014) suggesting that prosocial media is positively associated with prosocial behavior and empathic concern, and negatively associated with aggression. These findings hold across multiple contexts, such as age, methodology, region, media type, and several relating to the multidimensionality of prosocial behavior. These results have a number of implications for researchers, parents, media consumers, and media producers. We hope that researchers continue to examine prosocial behavior in the media. Compared to studies on media violence, for example, the overall number of studies focusing on prosocial media is relatively small. Additionally, we encourage parents and media consumers to seek out depictions of prosocial media in video games, films, TV programs, and music - and to consider the different types of prosocial messages that may be communicated (e.g., is the media depicting helping or volunteering, and is it toward a stranger or friend?). Currently, depictions of media violence reign supreme, with violent media far outselling prosocial media (Coyne \& Smith, 2014). We encourage media consumers to purchase and view prosocial media at higher levels and we encourage media producers to strategically create prosocial media that will attract consumers in positive ways. This is no easy task; however, we can change the media culture if researchers, parents, consumers, and producers work together to produce and purchase outstanding, interesting, and nuanced depictions of prosocial behavior in the media.

\section{References}

References marked with an asterisk indicate studies included in the meta-analysis.

\footnotetext{
*Abelman, R. (1985). Styles of parental disciplinary practices as a mediator of children's learning from prosocial television portrayals. Child Study Journal, 15, 131-146.
} 
Anderson, C. A., \& Bushman, B. J. (2002). Human aggression. Annual Review of Psychology, 53, 27-51. http://dx.doi.org/10.1146/annurev .psych.53.100901.135231

Anderson, C. A., Shibuya, A., Ihori, N., Swing, E. L., Bushman, B. J., Sakamoto, A., . . Saleem, M. (2010). Violent video game effects on aggression, empathy, and prosocial behavior in eastern and western countries: A meta-analytic review. Psychological Bulletin, 136, 151173. http://dx.doi.org/10.1037/a0018251

*Annie Jin, S. A. (2011). "My avatar behaves well and this feels right": Ideal and ought selves in video gaming. Social Behavior and Personality, 39, 1175-1182. http://dx.doi.org/10.2224/sbp.2011.39.9.1175

Arnett, J. J. (2000). Emerging adulthood. A theory of development from the late teens through the twenties. American Psychologist, 55, 469480 .

*Atkins, N., \& Greitemeyer, T. (2008). Effects of prosocial music on empathy and helping (Unpublished manuscript). Institute of Psychology, University of Innsbruck, Innsbruck, Austria.

*Bankart, C., \& Anderson, C. C. (1979). Short-term effects of prosocial television viewing on play of preschool boys and girls. Psychological Reports, 44, 935-941. http://dx.doi.org/10.2466/pr0.1979.44.3.935

Begg, C. B., \& Mazumdar, M. (1994). Operating characteristics of a rank correlation test for publication bias. Biometrics, 50, 1088-1101. http:// dx.doi.org/10.2307/2533446

*Böhm, T., Ruth, N., \& Schramm, H. (2016). 'Count on me'-The influence of music with prosocial lyrics on cognitive and affective aggression. Psychomusicology: Music, Mind, and Brain, 26, 279-283. http:// dx.doi.org/10.1037/pmu0000155

Borenstein, M., Hedges, L. V., Higgins, J. P., \& Rothstein, H. R. (2010). A basic introduction to fixed-effect and random-effects models for meta-analysis. Research Synthesis Methods, 1, 97-111. http://dx.doi.org/ $10.1002 / \mathrm{jrsm} .12$

Boxer, P., Groves, C. L., \& Docherty, M. (2015). Video games do indeed influence children and adolescents' aggression, prosocial behavior, and academic performance: A clearer reading of Ferguson (2015). Perspectives on Psychological Science, 10, 671-673. http://dx.doi.org/10.1177/ 1745691615592239

Buckley, K. E., \& Anderson, C. A. (2006). A theoretical model of the effects and consequences of playing video games. In P. Vorderer, J. Bryant, P. Vorderer, \& J. Bryant (Eds.), Playing video games: Motives, responses, and consequences (pp. 363-378). Mahwah, NJ: Lawrence Erlbaum.

Bushman, B. J., \& Huesmann, L. R. (2006). Short-term and long-term effects of violent media on aggression in children and adults. Archives of Pediatrics \& Adolescent Medicine, 160, 348-352. http://dx.doi.org/10 .1001/archpedi.160.4.348

Caird, J. K., Johnston, K. A., Willness, C. R., Asbridge, M., \& Steel, P. (2014). A meta-analysis of the effects of texting on driving. Accident; Analysis and Prevention, 71, 311-318. http://dx.doi.org/10.1016/j.aap .2014 .06 .005

Carlo, G., Crockett, L. J., Randall, B. A., \& Roesch, S. C. (2007). A latent growth curve analysis of prosocial behavior among rural adolescents. Journal of Research on Adolescence, 17, 301-324. http://dx.doi.org/10 .1111/j.1532-7795.2007.00524.x

Carlo, G., McGinley, M., Hayes, R. C., \& Martinez, M. M. (2011). Empathy as a mediator of the relations between parent and peer attachment and prosocial and physically aggressive behaviors in Mexican American college students. Journal of Social and Personal Relationships, 29, 337-357. http://dx.doi.org/10.1177/0265407511431181

Carlo, G., \& Randall, B. A. (2002). The development of a measure of prosocial behaviors for late adolescents. Journal of Youth and Adolescence, 31, 31-44. http://dx.doi.org/10.1023/A:1014033032440

*Chambers, J. H., \& Ascione, F. R. (1987). The effects of prosocial and aggressive videogames on children's donating and helping. The Journal of
Genetic Psychology, 148, 499-505. http://dx.doi.org/10.1080/00221325 1987.10532488

${ }^{*}$ Coyne, S. M., Jensen, A. C., Smith, N. J., \& Erickson, D. H. (2016). Super Mario brothers and sisters: Associations between coplaying video games and sibling conflict and affection. Journal of Adolescence, 47, 48-59. http://dx.doi.org/10.1016/j.adolescence.2015.12.001

"Coyne, S. M., Linder, J. R., Rasmussen, E. E., Nelson, D. A., \& Birkbeck, V. (2016). Pretty as a princess: Longitudinal effects of engagement with Disney princesses on gender stereotypes, body esteem, and prosocial behavior in children. Child Development, 87, 1909-1925. http://dx.doi org/10.1111/cdev.12569

Coyne, S. M., Nelson, D. A., \& Underwood, M. (2014). Aggression in children. In P. K. Smith, C. H. Hart, P. K. Smith, \& C. H. Hart (Eds.), The Wiley Blackwell handbook of childhood social development (2nd ed., pp. 491-509). Boston, MA: Wiley-Blackwell.

${ }^{*}$ Coyne, S. M., \& Padilla-Walker, L. M. (2015). Sex, violence, \& rock-nroll: Longitudinal effects of music on aggression, sex, and prosocial behavior during adolescence. Journal of Adolescence, 41, 96-104. http://dx.doi.org/10.1016/j.adolescence.2015.03.002

Coyne, S. M., Padilla-Walker, L. M., \& Howard, E. (2013). Emerging in a digital world: A decade review of media use, effects, and gratifications in emerging adulthood. Emerging Adulthood, 1, 125-137. http://dx.doi org/10.1177/2167696813479782

*Coyne, S. M., Poulsen, F., Fraser, A., Chiu, L., Cramer, C., \& Garcia, D. (2010). Effect of video games on different targets: An experimental study (Unpublished data). School of Family Life, Brigham Young University, Provo, UT.

Coyne, S. M., \& Smith, N. J. (2014). Sweetness on the screen: A multidimensional view of prosocial behavior in media. In L. M. PadillaWalker, G. Carlo, L. M. Padilla-Walker, \& G. Carlo (Eds.), Prosocial development: A multidimensional approach (pp. 156-177). New York, NY: Oxford University Press. http://dx.doi.org/10.1093/acprof:oso/ 9780199964772.003.0008

*de Leeuw, R. N., Kleemans, M., Rozendaal, E., Anschütz, D. J., \& Buijzen, M. (2015). The impact of prosocial television news on children's prosocial behavior: An experimental study in the Netherlands. Journal of Children and Media, 9, 1-16. http://dx.doi.org/10.1080/ 17482798.2015.1089297

*de Leeuw, R. N., \& van der Laan, C. A. (2017). Helping behavior in Disney animated movies and children's helping behavior: An experimental study (Unpublished manuscript). Communication Science, Radboud University, Nijmegan, the Netherlands.

Dill, K. E., Gentile, D. A., Richter, W. A., \& Dill, J. C. (2005). Violence, sex, race, and age in popular video games: A content analysis. In E Cole, J. H. Daniel, E. Cole, \& J. H. Daniel (Eds.), Featuring females. Feminist analyses of media (pp. 115-130). Washington, DC: American Psychological Association. http://dx.doi.org/10.1037/11213-008

Egger, M., Davey Smith, G., Schneider, M., \& Minder, C. (1997). Bias in meta-analysis detected by a simple, graphical test. British Medical Journal: British Medical Journal, 315, 629-634. http://dx.doi.org/10 $.1136 / \mathrm{bmj} .315 .7109 .629$

Eisenberg, N., Fabes, R. A., \& Spinrad, T. L. (2006). Prosocial development. In N. Eisenberg, W. Damon, R. M. Lerner, N. Eisenberg, W. Damon, \& R. M. Lerner (Eds.), Handbook of child psychology: Vol. 3. social, emotional, and personality development (6th ed., pp. 646-718). Hoboken, NJ: Wiley.

Eisenberg, N., \& Mussen, P. H. (1989). The roots of prosocial behavior in children. New York, NY: Cambridge University Press. http://dx.doi.org/ 10.1017/CBO9780511571121

Eisenberg, N., \& Spinrad, T. L. (2014). Multidimensionality of prosocial behavior: Rethinking the conceptualization and development of prosocial behavior. In L. M. Padilla-Walker, G. Carlo, L. M. Padilla-Walker, \& G. Carlo (Eds.), Prosocial development: A multidimensional ap 
proach (pp. 17-39). New York, NY: Oxford University Press. http://dx .doi.org/10.1093/acprof:oso/9780199964772.003.0002

*Farsides, T., Pettman, D., \& Tourle, L. (2013). Inspiring altruism: Reflecting on the personal relevance of emotionally evocative prosocial media characters. Journal of Applied Social Psychology, 43, 2251-2258. http://dx.doi.org/10.1111/jasp.12175

Ferguson, C. J. (2015). Do angry birds make for angry children? A meta-analysis of video game influences on children's and adolescents' aggression, mental health, prosocial behavior, and academic performance. Perspectives on Psychological Science, 10, 646-666. http://dx .doi.org/10.1177/1745691615592234

"Friedrich-Cofer, L. K., Huston-Stein, A., McBride Kipnis, D., Susman, E. J., \& Clewett, A. S. (1979). Environmental enhancement of prosocial television content: Effects on interpersonal behavior, imaginative play, and self-regulation in a natural setting. Developmental Psychology, 15, 637-646. http://dx.doi.org/10.1037/0012-1649.15.6.637

Gentile, D. (2009). Pathological video-game use among youth ages 8 to 18 : A national study. Psychological Science, 20, 594-602. http://dx.doi.org/ 10.1111/j.1467-9280.2009.02340.x

Gentile, D. (2014). Media violence and children (2nd ed.). Oxford, England: Praeger.

"Gentile, D. A., Anderson, C. A., Yukawa, S., Ihori, N., Saleem, M., Ming, L. K., .. . Sakamoto, A. (2009). The effects of prosocial video games on prosocial behaviors: International evidence from correlational, longitudinal, and experimental studies. Personality and Social Psychology Bulletin, 35, 752-763. http://dx.doi.org/10.1177/0146167209333045

Grabe, S., Ward, L. M., \& Hyde, J. S. (2008). The role of the media in body image concerns among women: A meta-analysis of experimental and correlational studies. Psychological Bulletin, 134, 460-476. http://dx .doi.org/10.1037/0033-2909.134.3.460

*Greitemeyer, T. (2009). Effects of songs with prosocial lyrics on prosocial behavior: Further evidence and a mediating mechanism. Personality and Social Psychology Bulletin, 35, 1500-1511. http://dx.doi.org/10.1177/ 0146167209341648

*Greitemeyer, T. (2009). Effects of songs with prosocial lyrics on prosocial thoughts, affect, and behavior. Journal of Experimental Social Psychology, 45, 186-190. http://dx.doi.org/10.1016/j.jesp.2008.08.003

*Greitemeyer, T. (2011). Effects of prosocial video games on aggression (Unpublished manuscript). Institute of Psychology, University of Innsbruck, Innsbruck, Austria.

*Greitemeyer, T. (2011). Exposure to music with prosocial lyrics reduces aggression: First evidence and test of the underlying mechanism. Journal of Experimental Social Psychology, 47, 28-36. http://dx.doi.org/10 .1016/j.jesp.2010.08.005

*Greitemeyer, T., Agthe, M., Turner, R., \& Gschwendtner, C. (2012). Acting prosocially reduces retaliation: Effects of prosocial video games on aggressive behavior. European Journal of Social Psychology, 42, 235-242. http://dx.doi.org/10.1002/ejsp.1837

Greitemeyer, T., \& Mügge, D. O. (2014). Video games do affect social outcomes: A meta-analytic review of the effects of violent and prosocial video game play. Personality and Social Psychology Bulletin, 40, $578-$ 589. http://dx.doi.org/10.1177/0146167213520459

*Greitemeyer, T., \& Osswald, S. (2008). Effects of prosocial video games on donations (Unpublished manuscript). Institute of Psychology, University of Innsbruck, Innsbruck, Austria.

*Greitemeyer, T., \& Osswald, S. (2009). Prosocial video games reduce aggressive cognitions. Journal of Experimental Social Psychology, 45, 896-900. http://dx.doi.org/10.1016/j.jesp.2009.04.005

"Greitemeyer, T., \& Osswald, S. (2010). Effects of prosocial video games on prosocial behavior. Journal of Personality and Social Psychology, 98, 211-221. http://dx.doi.org/10.1037/a0016997

*Greitemeyer, T., \& Osswald, S. (2011). Playing prosocial video games increases the accessibility of prosocial thoughts. The Journal of Social
Psychology, 151, 121-128. http://dx.doi.org/10.1080/002245409033 65588

*Greitemeyer, T., Osswald, S., \& Brauer, M. (2010). Playing prosocial video games increases empathy and decreases schadenfreude. Emotion, 10, 796-802. http://dx.doi.org/10.1037/a0020194

*Hackenberg, M., \& Greitemeyer, T. (2015). Do prosocial films influence behavior and if yes, why (Unpublished manuscript). Institute of Psychology, University of Innsbruck, Innsbruck, Austria.

Hardy, S. A., \& Carlo, G. (2005). Religiosity and prosocial behaviours in adolescence: The mediating role of prosocial values. Journal of Moral Education, 34, 231-249. http://dx.doi.org/10.1080/03057240500127210

*Harrington, B., \& O'Connell, M. (2016). Video games as virtual teachers: Prosocial video game use by children and adolescents from different socioeconomic groups is associated with increased empathy and prosocial behaviour. Computers in Human Behavior, 63, 650-658. http://dx doi.org/10.1016/j.chb.2016.05.062

Hearold, S. (1986). A synthesis of 1043 effects of television on social behavior. In G. Comstock (Ed.), Public communication and behavior (Vol. 1, pp. 65-133). New York, NY: Academic Press.

*Horne, M. (2011). Video games and the formation of virtue: An examination of the content of video games and their effect on compassion. Dissertation Abstracts International, 72, 2421. Retrieved from http:// mediaviolence.org/media-video-violence-addiction-research/researcharchives/horne-m-2011-video-games-and-the-formation-of-virtue-anexamination-of-the-content-of-video-games-and-their-effect-oncompassion-dissertation-abstracts-international-72/

Hunter, J. E., \& Schmidt, F. L. (1990). Dichotomization of continuous variables: The implications for meta-analysis. Journal of Applied Psychology, 75, 334-349. http://dx.doi.org/10.1037/0021-9010.75.3.334

Indlekofer, S., \& Greitemeyer, T. (2012). Effects of prosocial video games on prosocial cognitions, affect and emotion after a time delay (Unpublished manuscript). Institute of Psychology, University of Innsbruck, Innsbruck, Austria.

Johnson, B. T., \& Eagly, A. H. (2014). Meta-analysis of social-personality psychological research. CHIP Documents, Paper 35. Retrieved from http://digitalcommons.uconn.edu/cgi/viewcontent.cgi? article $=$ $1048 \&$ context $=$ chip_docs

*Kim, Y., \& Kim, N. (2008, November 21-24). Reconsidering the media priming effect on audiences' prosocial behavior: The effect of empathy as a mediating variable. Paper presented at the NCA 94th Annual Convention, San Diego, CA. Retrieved from http://citation.allacademic .com/meta/p_mla_apa_research_citation/2/5/7/5/1/p257516_index .html?phpsessid=d9cg83fb7eg8k42n26ut95d0r1

Laible, D., \& Karahuta, E. (2014). Prosocial behaviors in early childhood: Helping others, responding to the distress of others, and working with others. In L. M. Padilla-Walker \& G. Carlo (Eds.), Prosocial behavior: A multidimensional approach (pp. 350-373). New York, NY: Oxford University Press. http://dx.doi.org/10.1093/acprof:oso/9780199964772 .003 .0017

Lewis, M. B. E. (2014). Parents as recipients of adolescent prosocial behavior. In L. M. Padilla-Walker \& G. Carlo (Eds.), Prosocial behavior: A multidimensional approach (pp. 305-326). New York, NY: Oxford University Press. http://dx.doi.org/10.1093/acprof:oso/978019 9964772.003.0015

*Liu, Y., Teng, Z., Lan, H., Zhang, X., \& Yao, D. (2015). Short-term effects of prosocial video games on aggression: An event-related potential study. Frontiers in Behavioral Neuroscience, 9, 193. http://dx.doi .org/10.3389/fnbeh.2015.00193

Lull, R. B., \& Bushman, B. J. (2015). Do sex and violence sell? A meta-analytic review of the effects of sexual and violent media and ad content on memory, attitudes, and buying intentions. Psychological Bulletin, 141, 1022-1048. http://dx.doi.org/10.1037/bul0000018

Lull, R. B., \& Bushman, B. J. (2016). Immersed in violence: Presence mediates the effect of 3D violent video gameplay on angry feelings. 
Psychology of Popular Media Culture, 5, 133-144. http://dx.doi.org/10 .1037/ppm0000062

Maier, J. A., \& Gentile, D. A. (2012). Learning aggression through the media: Comparing psychological and communication approaches. In L. J. Shrum \& L. J. Shrum (Eds.), The psychology of entertainment media: Blurring the lines between entertainment and persuasion (2nd ed., pp. 271-303). New York, NY: Routledge/Taylor \& Francis Group.

Mano, R. S. (2014). Social media, social causes, giving behavior and money contributions. Computers in Human Behavior, 31, 287-293. http://dx.doi.org/10.1016/j.chb.2013.10.044

Mares, M. L. (1996). Positive effects of television on social behavior: A meta-analysis. Philadelphia, PA: Annenberg Public Policy Center of the University of Pennsylvania. Retrieved from https://www.annenbergpu blicpolicycenter.org/?s $=$ Positive + effects + of + television + on + social + behavior $\% 3 \mathrm{~A}+\mathrm{A}+$ meta-analysis

Mares, M., \& Pan, Z. (2013). Effects of Sesame Street: A meta-analysis of children's learning in 15 countries. Journal of Applied Developmental Psychology, 34, 140-151. http://dx.doi.org/10.1016/j.appdev.2013.01.001

Mares, M., \& Woodard, E. (2005). Positive effects of television on children's social interactions: A meta-analysis. Media Psychology, 7, 301322. http://dx.doi.org/10.1207/S1532785XMEP0703_4

Marshall, S. J., Biddle, S. J., Gorely, T., Cameron, N., \& Murdey, I. (2004). Relationships between media use, body fatness and physical activity in children and youth: A meta-analysis. International Journal of Obesity, 28, 1238-1246. http://dx.doi.org/10.1038/sj.ijo.0802706

"Möck, J., \& Greitemeyer, T. (2014). Why prosocial films influence behavior (Unpublished manuscript). Institute of Psychology, University of Innsbruck, Innsbruck, Austria.

Nielson, M. G., Padilla-Walker, L., \& Holmes, E. K. (2017). How do men and women help? Validation of a multidimensional measure of prosocial behavior. Journal of Adolescence, 56, 91-106. http://dx.doi.org/10 .1016/j.adolescence.2017.02.006

Nikkelen, S. W., Valkenburg, P. M., Huizinga, M., \& Bushman, B. J. (2014). Media use and ADHD-related behaviors in children and adolescents: A meta-analysis. Developmental Psychology, 50, 2228-2241. http://dx.doi.org/10.1037/a0037318

*Nitzsche, T., \& Greitemeyer, T. (2012). Effects of prosocial music on empathy toward animals (Unpublished manuscript). Institute of Psychology, University of Innsbruck, Innsbruck, Austria.

*Niven, K. (2015). Can music with prosocial lyrics heal the working world? A field intervention in a call center. Journal of Applied Social Psychology, 45, 132-138. http://dx.doi.org/10.1111/jasp.12282

Orwin, R. G. (1983). A fail-safe $N$ for effect size in meta-analysis. Journal of Educational Statistics, 8, 157-159. http://dx.doi.org/10.2307/1164923

Padilla-Walker, L. M., \& Carlo, G. (2014). Prosocial behavior: Past, present, and future. In L. M. Padilla-Walker \& G. Carlo (Eds.), Prosocial behavior: A multidimensional approach (pp. 3-16). New York, NY: Oxford University Press. http://dx.doi.org/10.1093/acprof:oso/ 9780199964772.003.0001

Padilla-Walker, L. M., Carlo, G., \& Nielson, M. G. (2015). Does helping keep teens protected? Longitudinal bidirectional relations between prosocial behavior and problem behavior. Child Development, 86, 1759-1772. http://dx.doi.org/10.1111/cdev.12411

Padilla-Walker, L. M., \& Christensen, K. J. (2011). Empathy and selfregulation as mediators between parenting and adolescents' prosocial behavior toward strangers, friends, and family. Journal of Research on Adolescence, 21, 545-551. http://dx.doi.org/10.1111/j.1532-7795.2010 .00695.x

"Padilla-Walker, L. M., Coyne, S. M., Collier, K. M., \& Nielson, M. G. (2015). Longitudinal relations between prosocial television content and adolescents' prosocial and aggressive behavior: The mediating role of empathic concern and self-regulation. Developmental Psychology, 51, 1317-1328. http://dx.doi.org/10.1037/a0039488
Padilla-Walker, L. M., Coyne, S. M., Fraser, A. M., \& Stockdale, L. A. (2013). Is Disney the nicest place on earth? A content analysis of prosocial behavior in animated Disney films. Journal of Communication, 63, 393-412. http://dx.doi.org/10.1111/jcom.12022

Padilla-Walker, L. M., \& Fraser, A. M. (2014). How much is it going to cost me? Bidirectional relations between adolescents' moral personality and prosocial behavior. Journal of Adolescence, 37, 993-1001. http:// dx.doi.org/10.1016/j.adolescence.2014.07.008

Persky, S., \& Blascovich, J. (2007). Immersive virtual environments versus traditional platforms: Effects of violent and nonviolent video game play. Media Psychology, 10, 135-156.

*Petikas, N. C. (2013). Effects of prosocial video games on state anger and helping behavior. Retrieved from http://search.proquest.com/docview/ 1418021239? accountid $=4488$

*Pieschl, S., \& Fegers, S. (2015). Violent Lyrics = Aggressive Listeners? Effects of song lyrics and tempo on cognition, affect, and self-reported arousal. Journal of Media Psychology, 28, 32-41. https:// doi.org/10.1027/1864-1105/a000144

*Prot, S., Gentile, D. A., Anderson, C. A., Suzuki, K., Swing, E., Lim, K. M., . . Lam, B. C. (2014). Long-term relations among prosocialmedia use, empathy, and prosocial behavior. Psychological Science, 25, 358-368. http://dx.doi.org/10.1177/0956797613503854

Quinn, K. (2013). We haven't talked in 30 years! Relationship reconnection and internet use at midlife. Information Communication and Society, 16, 397-420. http://dx.doi.org/10.1080/1369118X.2012.756047

Rideout, V. (2015). The common sense census: Media use by tweens and teens. Retrieved from https://www.commonsensemedia.org/research/ the-common-sense-census-media-use-by-tweens-and-teens

*Rosenberg, R. S., Baughman, S. L., \& Bailenson, J. N. (2013). Virtual superheroes: Using superpowers in virtual reality to encourage prosocial behavior. PLOS ONE, 8, e55003. http://dx.doi.org/10.1371/journal.pone .0055003

*Rosenkoetter, L. I. (1999). The television situation comedy and children's prosocial behavior. Journal of Applied Social Psychology, 29, 979-993. http://dx.doi.org/10.1111/j.1559-1816.1999.tb00135.x

Rosenthal, R. (1994). Parametric measures of effect size. In H. Cooper \& L. V. Hedges (Eds.), The handbook of research synthesis (p. 239). New York, NY: SAGE.

Rothstein, H. R., \& Bushman, B. J. (2015). Methodological and reporting errors in meta-analytic reviews make other meta-analysts angry: A commentary on Ferguson (2015). Perspectives on Psychological Science, 10, 677-679. http://dx.doi.org/10.1177/1745691615592235

"Ruth, N. (2017). 'Heal the world': A field experiment on the effects of music with prosocial lyrics on prosocial behavior. Psychology of Music, 45, 298-304. http://dx.doi.org/10.1177/0305735616652226

*Saleem, M., Anderson, C. A., \& Gentile, D. A. (2012). Effects of prosocial, neutral, and violent video games on children's helpful and hurtful behaviors. Aggressive Behavior, 38, 281-287. http://dx.doi.org/10.1002/ ab. 21428

*Saleem, M., Anderson, C. A., \& Gentile, D. A. (2012). Effects of prosocial, neutral, and violent video games on college students' affect. Aggressive Behavior, 38, 263-271. http://dx.doi.org/10.1002/ab.21427

${ }^{*}$ Schmid, R., \& Greitemeyer, T. (2015). Do prosocial films increase empathy and helping? (Unpublished manuscript). Institute of Psychology, University of Innsbruck, Innsbruck, Austria.

Silver, N. C., \& Dunlap, W. P. (1987). Averaging correlation coefficients: Should Fisher's z transformation be used? Journal of Applied Psychology, 72, 146-148. http://dx.doi.org/10.1037/0021-9010.72.1.146

*Smith, N. (2015). Does video game content matter? An examination of two competing ideas (Unpublished doctoral dissertation). School of Family Life, Brigham Young University, Provo, UT.

Smith, S. W., Smith, S. L., Pieper, K. M., Yoo, J. H., Ferris, A. L., Downs, E., \& Bowden, B. (2006). Altruism on American television: Examining the amount of, and context surrounding, acts of helping and sharing. 
Journal of Communication, 56, 707-727. http://dx.doi.org/10.1111/j .1460-2466.2006.00316.x

Song, H., Zmyslinski-Seelig, A., Kim, J., Drent, A., Victor, A., Omori, K., \& Allen, M. (2014). Does Facebook make you lonely? A meta-analysis. Computers in Human Behavior, 36, 446-452. http://dx.doi.org/10.1016/ j.chb.2014.04.011

*Sprafkin, J. N., Liebert, R. M., \& Poulos, R. W. (1975). Effects of a prosocial televised example on children's helping. Journal of Experimental Child Psychology, 20, 119-126. http://dx.doi.org/10.1016/00220965(75)90031-4

*Tamborini, R., Lewis, R. J., Prabhu, S., Grizzard, M. N., \& Eden, A. (2012, May 24-28). Priming morality: The influence of media exposure on moral intuitions. Paper presented at the 62nd Annual Conference of the International Communication Association, Phoenix, AZ.

*Teachman, G., \& Orme, M. (1981). Effects of aggressive and prosocial film material on altruistic behavior of children. Psychological Reports, 48, 699-702. http://dx.doi.org/10.2466/pr0.1981.48.3.699

*Toeplitz-Winiewska, M. (1977). Influence of various models on aggressive behavior in individuals with different socialization experience. Polish Psychological Bulletin, 8, 215-222.

Trepanier, M. L., \& Romatowski, J. A. (1982). Classroom use of selected children's books: Prosocial development in young children. The Journal of Humanistic Counseling, Education and Development, 21, 36-42. http://dx.doi.org/10.1002/j.2164-4683.1982.tb00211.x

"Tsai, Y., \& Kaufman, D. M. (2009). The socioemotional effects of a computer-simulated animal on children's empathy and humane attitudes.
Journal of Educational Computing Research, 41, 103-122. http://dx.doi org/10.2190/EC.41.1.e

*Tsay-Vogel, M., \& Krakowiak, K. M. (2016). Inspirational reality TV: The prosocial effects of lifestyle transforming reality programs on elevation and altruism. Journal of Broadcasting \& Electronic Media, 60, 567-586. http://dx.doi.org/10.1080/08838151.2016.1234474

*Ullrich, H., \& Greitemeyer, T. (2011). Effects of prosocial video games on empathy and donations (Unpublished manuscript). Institute of Psychology, University of Innsbruck, Innsbruck, Austria.

Valkenburg, P. M. (2015). The limited informativeness of meta-analyses of media effects. Perspectives on Psychological Science, 10, 680-682. http://dx.doi.org/10.1177/1745691615592237

*Vieira, E. T., Jr. (2014). The relationships among girls' prosocial video gaming, perspective-taking, sympathy, and thoughts about violence. Communication Research, 41, 892-912. http://dx.doi.org/10.1177/ 0093650212463049

*Woolf, K. D. (2009). Children, parents and prosocial television for children: Accounting for viewing and looking for effects. Retrieved from http://search.proquest.com.erl.lib.byu.edu/docview/250936860?ac countid $=4488$
Received October 4, 2016

Revision received June 30, 2017

Accepted July 24, 2017 